\title{
Sulfated and Sulfur-Containing Steroids and Their Pharmacological Profile
}

\author{
Tatyana A. Pounina ${ }^{1}$, Tatyana A. Gloriozova ${ }^{2}$, Nick Savidov ${ }^{3}$ and Valery M. Dembitsky ${ }^{3,4, *}$ \\ 1 Far Eastern Geological Institute, Russian Academy of Sciences, 159 Prospect 100-letiya Vladivostoka, \\ 690022 Vladivostok, Russia; pounta@mail.ru \\ 2 Institute of Biomedical Chemistry, 10 Building 8, Pogodinskaya Street, 119121 Moscow, Russia; \\ tatyana.gloriozova@ibmc.msk.ru \\ 3 Centre for Applied Research, Innovation and Entrepreneurship, Lethbridge College, \\ 3000 College Drive South, Lethbridge, AB T1K 1L6, Canada; nick.savidov@lethbridgecollege.ca \\ 4 A.V. Zhirmunsky National Scientific Center of Marine Biology, 17 Palchevsky Str., 690041 Vladivostok, Russia \\ * Correspondence: valery.dembitsky@lethbridgecollege.ca; Tel.: +403-320-3202 (ext. 5463); Fax: +1-888-858-8517
}

Citation: Pounina, T.A.;

Gloriozova, T.A.; Savidov, N.; Dembitsky, V.M. Sulfated and Sulfur-Containing Steroids and Their Pharmacological Profile. Mar. Drugs 2021, 19, 240. https://doi.org/ $10.3390 / \operatorname{md} 19050240$

Academic Editor: Hitoshi Sashiwa

Received: 20 March 2021

Accepted: 22 April 2021

Published: 24 April 2021

Publisher's Note: MDPI stays neutral with regard to jurisdictional claims in published maps and institutional affiliations.

Copyright: (c) 2021 by the authors. Licensee MDPI, Basel, Switzerland. This article is an open access article distributed under the terms and conditions of the Creative Commons Attribution (CC BY) license (https:/ / creativecommons.org/licenses/by/ $4.0 /)$.

\begin{abstract}
The review focuses on sulfated steroids that have been isolated from seaweeds, marine sponges, soft corals, ascidians, starfish, and other marine invertebrates. Sulfur-containing steroids and triterpenoids are sourced from sedentary marine coelenterates, plants, marine sediments, crude oil, and other geological deposits. The review presents the pharmacological profile of sulfated steroids, sulfur-containing steroids, and triterpenoids, which is based on data obtained using the PASS program. In addition, several semi-synthetic and synthetic epithio steroids, which represent a rare group of bioactive lipids that have not yet been found in nature, but possess a high level of antitumor activity, were included in this review for the comparative pharmacological characterization of this class of compounds. About 140 steroids and triterpenoids are presented in this review, which demonstrate a wide range of biological activities. Therefore, out of 71 sulfated steroids, thirteen show strong antitumor activity with a confidence level of more than $90 \%$, out of 50 sulfur-containing steroids, only four show strong antitumor activity with a confidence level of more than $93 \%$, and out of eighteen epithio steroids, thirteen steroids show strong antitumor activity with a confidence level of $91 \%$ to $97.4 \%$.
\end{abstract}

Keywords: sulfated; sulfur-containing; epithio; steroids; pharmacology; antitumor; marine; PASS

\section{Introduction}

Sulfur is one of the most abundant chemical elements in nature [1,2]. In addition, sulfur is found in many classes of organic compounds such as peptides, various terpenoids and steroids, and other compounds [1-16]. More than 3000 different sulfur compounds are found in various ecological niches, including oceans and freshwater lakes, volcanic gases, sediments, and rocks [12-22]. Many photosynthetic organisms such as algae and phytoplankton assimilate sulfur as sulfate. Sulfate is generally readily available in aquatic ecosystems for many marine and freshwater organisms [1-4,9,10,14,18,20,23-27]. The biochemistry and geochemistry of sulfur are currently well studied, and many publications are devoted to this topic [1-18,21-42].

Sulfated compounds, including steroids, are widely distributed in nature [1-8]. Sulfated steroids and triterpenoids are found in many animals, reptiles, and humans [9-14]. In addition, these compounds are present in extracts of plants and some shrubs, produced by microorganisms, fungi, and found in many marine invertebrates such as brittle star, starfish, sponges, ascidian, snails, and algae [2,15-21].

Studies of the last decades of marine sediments have shown that extracts from these geological formations contain a wide variety of steroids, terpenoids, and other lipids [22-29]. These findings indicate that such a variety of lipids is of organic origin, and, apparently, 
the producers are bacteria, terrestrial higher plants, unicellular and diatom algae, marine invertebrates, and other organisms [22,23,30]. Interestingly, sterols, triterpenoids, and even boron-containing compounds were found in marine sediments of the Cretaceous period more than 150 million years ago [31-38]. Sulfur-containing steroids and terpenoids are found in ancient earth rocks, crude oil, and other marine and aquatic sediments [39-42]. There is still no convincing evidence that microorganisms are not involved in the formation of sulfur-containing steroids and terpenoids, but, nevertheless, these lipid markers are of great interest for geochemistry, biochemistry, medicinal chemistry, and pharmacology [43-45].

This review focuses on sulfated steroids and triterpenoids that have been found and isolated from marine sources such as algae, sponges, and other marine invertebrates. The review also presents sulfur-containing steroids and triterpenoids isolated from soft corals, marine sediments, and crude oil and other geological deposits. In addition, we have included in this review several semi-synthetic and synthetic epithio steroids, which represent a rare group of bioactive lipids and have not yet been found in nature but exhibit a high level of antitumor activity. For all natural, semi-synthetic and synthetic compounds included in this review, their pharmacological profile and specific diversity of biological activity are presented.

\section{Mono Sulfated Steroids Derived from Marine Sources}

It is known that sulfated steroids are of potential interest for practical and clinical medicine, due to the fact that many of them exhibit a wide range of biological activities; however, the activity of many sulfated steroids has not been determined $[2,9,10,15-18,21,46]$.

Two sulfated steroids, (1, for for structure see Figure 1 and for activities see Table 1) and (2), were obtained from a lipophilic extract of an undescribed bryozoan species in the genus Calyptotheca. Both isolated metabolites exhibited moderate cytotoxicity at $\mathrm{IC}_{50} 54$ and $30 \mu \mathrm{M}$, respectively, against the rat bladder carcinoma epithelial NBT-T2 cell line [47].

Table 1. Biological activities of sulfated steroids.

\begin{tabular}{|c|c|c|c|}
\hline No. & Antitumor \& Related Activity, (Pa) * & Violation of Lipid Metabolism, $(\mathrm{Pa})^{*}$ & Additional Predicted Activity, $(\mathbf{P a}) *$ \\
\hline \multirow{2}{*}{1} & Antineoplastic (0.887) & Anti-hypercholesterolemic (0.901) & Hemostatic (0.931) \\
\hline & Chemopreventive (0.815) & Cholesterol synthesis inhibitor (0.822) & Biliary tract disorders treatment $(0.814)$ \\
\hline \multirow{2}{*}{2} & Antineoplastic (0.906) & Anti-hypercholesterolemic (0.895) & Hemostatic (0.927) \\
\hline & Chemopreventive (0.816) & Cholesterol synthesis inhibitor $(0.816)$ & Biliary tract disorders treatment $(0.819)$ \\
\hline \multirow{3}{*}{3} & Antineoplastic (0.828) & Atherosclerosis treatment $(0.786)$ & Hepatoprotectant (0.832) \\
\hline & Chemopreventive (0.735) & Cholesterol synthesis inhibitor (0.733) & Anti-inflammatory $(0.807)$ \\
\hline & Apoptosis agonist (0.703) & Anti-hypercholesterolemic (0.711) & Biliary tract disorders treatment $(0.717)$ \\
\hline \multirow{2}{*}{4} & Antineoplastic (0.778) & Cholesterol synthesis inhibitor (0.762) & Biliary tract disorders treatment $(0.752)$ \\
\hline & Chemopreventive (0.802) & Atherosclerosis treatment $(0.744)$ & Anti-ischemic, cerebral (0.774) \\
\hline \multirow{2}{*}{5} & Chemopreventive (0.843) & Atherosclerosis treatment $(0.721)$ & Biliary tract disorders treatment $(0.713)$ \\
\hline & Antineoplastic (0.804) & Cholesterol synthesis inhibitor $(0.744)$ & Wound-healing agent $(0.831)$ \\
\hline \multirow[b]{2}{*}{6} & Antineoplastic (0.880) & Cholesterol synthesis inhibitor (0.774) & Wound-healing agent (0.866) \\
\hline & Apoptosis agonist (0.865) & Anti-hypercholesterolemic (0.821) & Biliary tract disorders treatment $(0.764)$ \\
\hline \multirow{3}{*}{7} & Antineoplastic (0.877) & Cholesterol synthesis inhibitor (0.776) & Wound-healing agent (0.852) \\
\hline & Chemopreventive (0.722) & Cholesterol synthesis inhibitor (0.755) & Hemostatic (0.757) \\
\hline & Apoptosis agonist $(0.712)$ & Anti-hypercholesterolemic (0.732) & Biliary tract disorders treatment $(0.741)$ \\
\hline \multirow{2}{*}{8} & Chemopreventive (0.857) & Anti-hypercholesterolemic (0.884) & Biliary tract disorders treatment $(0.871)$ \\
\hline & Antineoplastic (0.765) & Cholesterol synthesis inhibitor $(0.766)$ & Hemostatic (0.736) \\
\hline \multirow{3}{*}{9} & Antineoplastic (0.904) & Atherosclerosis treatment $(0.889)$ & Biliary tract disorders treatment $(0.911)$ \\
\hline & Chemopreventive (0.843) & Cholesterol synthesis inhibitor $(0.821)$ & Anti-inflammatory $(0.821)$ \\
\hline & Apoptosis agonist (0.721) & Anti-hypercholesterolemic (0.820) & Biliary tract disorders treatment $(0.724)$ \\
\hline \multirow{3}{*}{10} & Chemopreventive (0.879) & Cholesterol synthesis inhibitor (0.862) & Wound-healing agent (0.872) \\
\hline & Apoptosis agonist (0.850) & Atherosclerosis treatment $(0.862)$ & Biliary tract disorders treatment $(0.753)$ \\
\hline & Antineoplastic (0.824) & Anti-hypercholesterolemic (0.812) & Hemostatic (0.731) \\
\hline
\end{tabular}


Table 1. Cont.

\begin{tabular}{|c|c|c|c|}
\hline No. & Antitumor \& Related Activity, $(\mathbf{P a})$ * & Violation of Lipid Metabolism, $(\mathrm{Pa})^{*}$ & Additional Predicted Activity, $(\mathbf{P a}) *$ \\
\hline 11 & $\begin{array}{l}\text { Chemopreventive }(0.882) \\
\text { Antineoplastic }(0.773) \\
\text { Apoptosis agonist }(0.748)\end{array}$ & $\begin{array}{c}\text { Cholesterol synthesis inhibitor }(0.869) \\
\text { Atherosclerosis treatment }(0.858) \\
\text { Anti-hypercholesterolemic }(0.823)\end{array}$ & $\begin{array}{c}\text { Biliary tract disorders treatment }(0.762) \\
\text { Hemostatic }(0.739)\end{array}$ \\
\hline 12 & $\begin{array}{l}\text { Chemopreventive }(0.873) \\
\text { Antineoplastic }(0.778) \\
\text { Apoptosis agonist }(0.751)\end{array}$ & $\begin{array}{c}\text { Cholesterol synthesis inhibitor }(0.861) \\
\text { Atherosclerosis treatment }(0.844) \\
\text { Anti-hypercholesterolemic }(0.832)\end{array}$ & $\begin{array}{l}\text { Biliary tract disorders treatment }(0.812) \\
\text { Wound-healing agent }(0.775)\end{array}$ \\
\hline 13 & $\begin{array}{l}\text { Antineoplastic }(0.902) \\
\text { Chemopreventive }(0.878)\end{array}$ & $\begin{array}{l}\text { Cholesterol synthesis inhibitor }(0.855) \\
\text { Anti-hypercholesterolemic }(0.831)\end{array}$ & Wound-healing agent (0.884) \\
\hline
\end{tabular}

* Only activities with $\mathrm{Pa}>0.5$ are shown.<smiles>C=C[C@H](C)C1CCC2[C@H]3CCC4=CC(=O)C=C[C@]4(C)[C@H]3CC[C@@]12C</smiles><smiles>CCCC(C)CO[R6](=O)O[Na]</smiles>

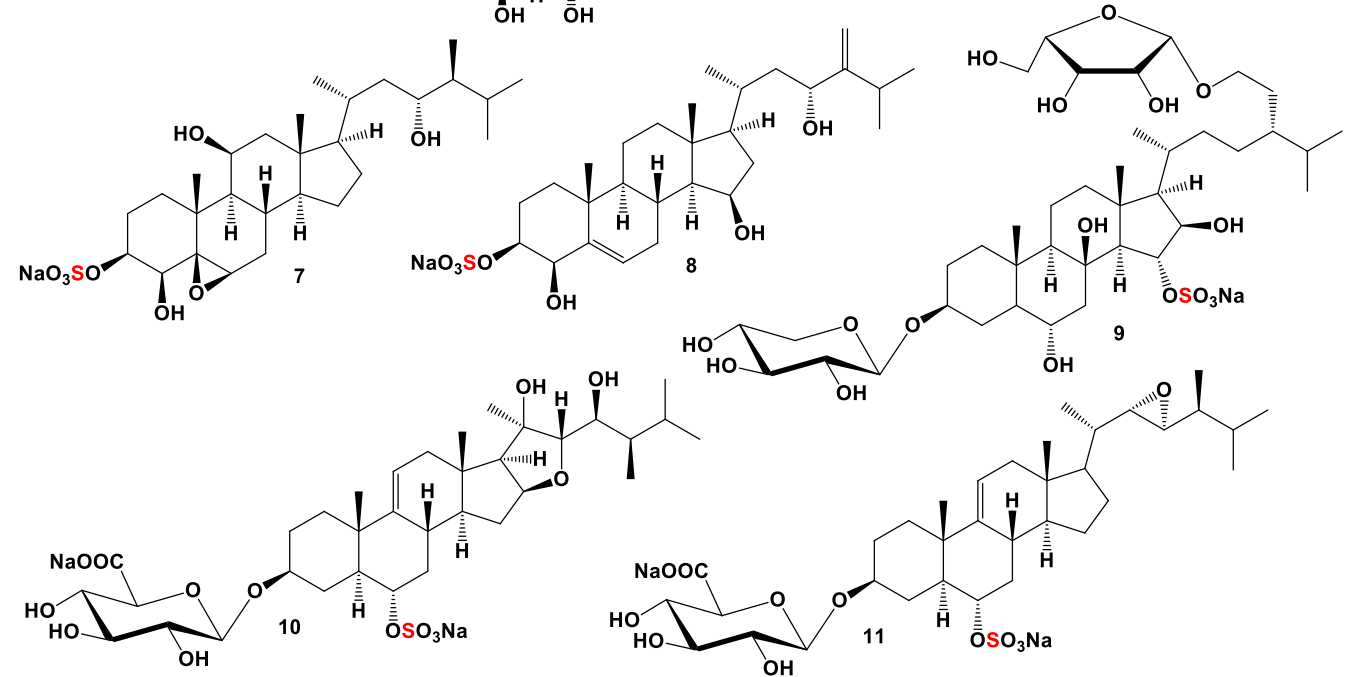

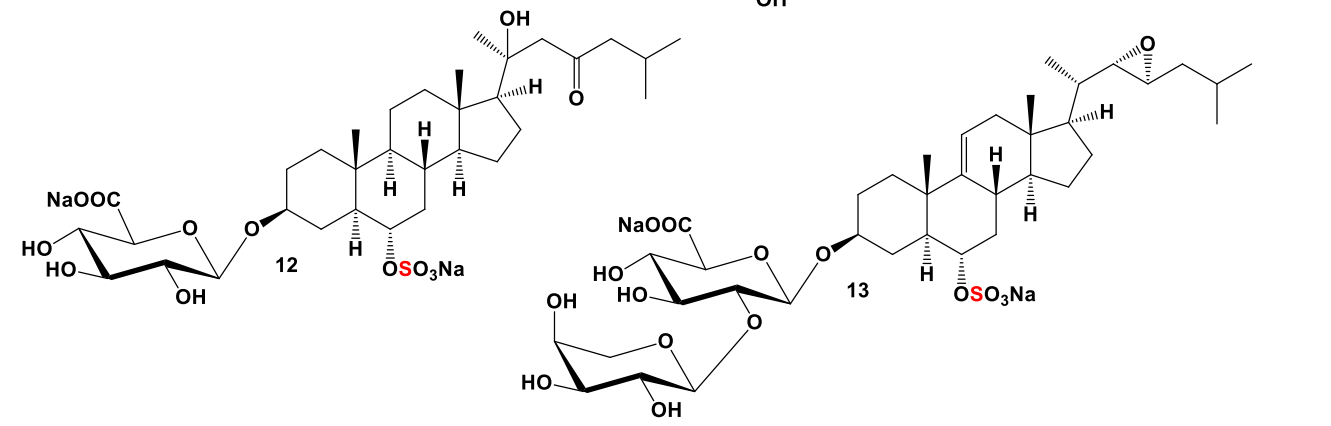

Figure 1. Mono sulfated steroids are derived from marine sources, and their pharmacological profile is shown in Table 1. 
Several sulfated steroids have been found and isolated from the marine starfish. Thus, sulfated polyhydroxysteroid named microdiscusol G (3) was isolated from the Arctic starfish Asterias microdiscus. The 28-sulfooxy-24-methylcholestane side chain in (3) has been found among starfish steroid metabolites for the first time [48]. Two steroids (4 and 5) and an unusual glucoside (6) were isolated from the starfish Archaster typicus collected in shallow waters of the Quang Ninh province (Vietnam). Isolated compounds showed moderate toxic effects in the sperm and 8-blastomere tests on embryonal development of the sea urchin Strongylocentrotus intermedius [49,50].

Polyoxygenated steroids belonging to a new structural group of sponge steroids called gracilosulfates B (7) and D (8) were isolated from the marine sponge Haliclona gracilis. Both compounds inhibited the expression of prostate-specific antigen in a human prostate carcinoma epithelial tumor cell lines (22Rv1) [51]. Steroid glycoside, granulatosides D (9), belonging to the group of bi- and monoglycosides of polyhydroxysteroids, respectively, was isolated from the ethanolic extract of the starfish Choriaster granulatus. The obtained compound showed immunomodulatory properties, increasing the intracellular ROS (reactive oxygen species) level in peritoneal murine macrophages by $20 \%$ and decreasing intracellular ROS level by $21 \%$ in pre-treated with endotoxic lipopolysaccharide from $E$. coli peritoneal macrophages [52].

Several starfish polar steroids, downeyosides A (10), C (11), J (12), and H (13) sulfated steroid glucuronides, were isolated from the starfish Henricia downeyae (family Echinasteridae) collected in the northern Gulf of Mexico [53,54].

Cholesterol sulphate (14, structure see Figure 2 and activities see Table 2) has been isolated from the starfish Asterias rubens [55,56], and compound (14) and cholestanol sulphate (15) were identified as the major components among the 34 different sterol sulfates of the sea cucumber Eupentacta fraudatrix [57].

Table 2. Biological activities of mono sulfated steroids.

\begin{tabular}{|c|c|c|c|}
\hline No. & Antitumor \& Related Activity, (Pa) * & Violation of Lipid Metabolism, $(\mathrm{Pa})$ * & Additional Predicted Activity, $(\mathrm{Pa}) *$ \\
\hline \multirow{2}{*}{14} & Chemopreventive (0.828) & Anti-hypercholesterolemic (0.919) & Wound-healing agent (0.975) \\
\hline & Antineoplastic (0.798) & Cholesterol synthesis inhibitor (0.803) & Biliary tract disorders treatment $(0.861)$ \\
\hline \multirow{2}{*}{15} & Antineoplastic (0.780) & Anti-hypercholesterolemic (0.874) & Biliary tract disorders treatment (0.955) \\
\hline & Chemopreventive (0.766) & Cholesterol synthesis inhibitor (0.789) & Wound-healing agent (0.945) \\
\hline \multirow{3}{*}{16} & Chemopreventive (0.841) & Anti-hypercholesterolemic (0.907) & Wound-healing agent (0.846) \\
\hline & Antineoplastic (0.804) & Cholesterol synthesis inhibitor $(0.818)$ & Biliary tract disorders treatment $(0.823)$ \\
\hline & Prostate disorders treatment $(0.675)$ & Atherosclerosis treatment $(0.724)$ & Hepatoprotectant (0.816) \\
\hline \multirow{3}{*}{17} & Antineoplastic (0.858) & Anti-hypercholesterolemic (0.886) & Biliary tract disorders treatment $(0.801)$ \\
\hline & Chemopreventive (0.797) & Cholesterol synthesis inhibitor (0.753) & Wound-healing agent (0.783) \\
\hline & Apoptosis agonist (0.719) & Atherosclerosis treatment $(0.699)$ & Hepatoprotectant $(0.771)$ \\
\hline \multirow{2}{*}{18} & Antineoplastic (0.791) & Anti-hypercholesterolemic (0.909); & 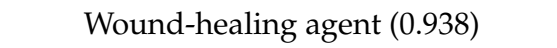 \\
\hline & Prostate disorders treatment $(0.692)$ & Cholesterol synthesis inhibitor (0.806); & Biliary tract disorders treatment $(0.850)$ \\
\hline \multirow{2}{*}{19} & Chemopreventive (0.887) & Anti-hypercholesterolemic (0.940) & Wound-healing agent (0.952) \\
\hline & Antineoplastic (0.803) & Cholesterol synthesis inhibitor (0.815); & Hepatoprotectant (0.876) \\
\hline \multirow{2}{*}{20} & Chemopreventive (0.828) & Anti-hypercholesterolemic (0.919); & Wound-healing agent (0.975) \\
\hline & Antineoplastic (0.798) & Cholesterol synthesis inhibitor $(0.803)$ & Biliary tract disorders treatment $(0.861)$ \\
\hline \multirow{3}{*}{21} & Chemopreventive (0.934) & Anti-hypercholesterolemic (0.912) & Hemostatic (0.928) \\
\hline & Antineoplastic (0.867) & Atherosclerosis treatment $(0.776)$ & Biliary tract disorders treatment $(0.764)$ \\
\hline & Apoptosis agonist (0.857) & Cholesterol synthesis inhibitor $(0.750)$ & Wound-healing agent (0.727) \\
\hline \multirow{2}{*}{22} & Chemopreventive (0.891) & Anti-hypercholesterolemic (0.789) & Wound-healing agent (0.816) \\
\hline & Antineoplastic (0.791) & Cholesterol synthesis inhibitor $(0.788)$; & Biliary tract disorders treatment $(0.807)$ \\
\hline \multirow{2}{*}{23} & Antineoplastic (0.822) & Anti-hypercholesterolemic (0.926) & Biliary tract disorders treatment (0.879); \\
\hline & Chemopreventive (0.806) & Atherosclerosis treatment $(0.804)$ & Hepatoprotectant (0.764) \\
\hline \multirow{2}{*}{24} & Antineoplastic (0.781) & Anti-hypercholesterolemic (0.929); & Biliary tract disorders treatment (0.910); \\
\hline & Chemopreventive (0.780) & Cholesterol synthesis inhibitor $(0.762)$ & Hepatoprotectant $(0.876)$ \\
\hline
\end{tabular}


Table 2. Cont.

\begin{tabular}{|c|c|c|c|}
\hline No. & Antitumor \& Related Activity, (Pa) * & Violation of Lipid Metabolism, $(\mathrm{Pa}) *$ & Additional Predicted Activity, $(\mathrm{Pa}) *$ \\
\hline 25 & $\begin{array}{l}\text { Chemopreventive }(0.837) \\
\text { Antineoplastic }(0.777)\end{array}$ & $\begin{array}{l}\text { Acute neurologic disorders treatment } \\
\qquad(0.808) \\
\text { Cholesterol synthesis inhibitor (0.719); }\end{array}$ & $\begin{array}{l}\text { Wound-healing agent }(0.895) \\
\text { Hepatoprotectant }(0.888)\end{array}$ \\
\hline 26 & $\begin{array}{l}\text { Chemopreventive }(0.902) \\
\text { Apoptosis agonist }(0.894) \\
\text { Antineoplastic }(0.866)\end{array}$ & $\begin{array}{c}\text { Anti-hypercholesterolemic }(0.931) \\
\text { Atherosclerosis treatment }(0.807) \\
\text { Cholesterol synthesis inhibitor }(0.732)\end{array}$ & $\begin{array}{c}\text { Biliary tract disorders treatment }(0.844) \\
\text { Hepatic disorders treatment }(0.818) \\
\text { Wound-healing agent }(0.556)\end{array}$ \\
\hline 27 & $\begin{array}{l}\text { Chemopreventive }(0.850) \\
\text { Antineoplastic }(0.777)\end{array}$ & $\begin{array}{l}\text { Anti-hypercholesterolemic (0.897); } \\
\text { Cholesterol synthesis inhibitor (0.819); }\end{array}$ & $\begin{array}{l}\text { Hepatoprotectant }(0.879) \\
\text { Biliary tract disorders treatment }(0.866)\end{array}$ \\
\hline 28 & $\begin{array}{l}\text { Chemopreventive }(0.944) \\
\text { Apoptosis agonist }(0.808)\end{array}$ & $\begin{array}{l}\text { Cholesterol synthesis inhibitor }(0.714) \\
\text { Atherosclerosis treatment }(0.708)\end{array}$ & $\begin{array}{l}\text { Hepatoprotectant }(0.872) \\
\text { Antifungal }(0.831)\end{array}$ \\
\hline 29 & $\begin{array}{l}\text { Chemopreventive }(0.913) \\
\text { Antineoplastic }(0.796) \\
\text { Apoptosis agonist }(0.790)\end{array}$ & $\begin{array}{c}\text { Cholesterol synthesis inhibitor }(0.762) \\
\text { Anti-hypercholesterolemic }(0.726) \\
\text { Atherosclerosis treatment }(0.717)\end{array}$ & $\begin{array}{l}\text { Wound-healing agent }(0.965) \\
\text { Hepatoprotectant }(0.933) \\
\text { Biliary tract disorders treatment }(0.791)\end{array}$ \\
\hline 30 & $\begin{array}{l}\text { Antineoplastic }(0.772) \\
\text { Chemopreventive }(0.715)\end{array}$ & $\begin{array}{c}\text { Atherosclerosis treatment }(0.611) \\
\text { Cholesterol synthesis inhibitor }(0.550)\end{array}$ & $\begin{array}{l}\text { Hepatoprotectant }(0.893) \\
\text { Erythropoiesis stimulant }(0.789)\end{array}$ \\
\hline 31 & $\begin{array}{l}\text { Chemopreventive }(0.882) \\
\text { Antineoplastic }(0.803)\end{array}$ & $\begin{array}{l}\text { Anti-hypercholesterolemic }(0.906) \\
\text { Cholesterol synthesis inhibitor }(0.823)\end{array}$ & $\begin{array}{l}\text { Biliary tract disorders treatment }(0.847) \\
\text { Hepatoprotectant }(0.812)\end{array}$ \\
\hline
\end{tabular}

The 24-methylidene-cholesterol sulfate (16) was detected in the diatomic microalga Nitzchia alba more than 50 years ago [58], and another derivative of cholesterol sulfate called hymenosulfate (17) with an unusual side chain was found in the haptophytic microalga Hymenomonas sp. [59]. Three sulfated sterols, (14), 24-methylcholest-5-en-3 $\beta$ ol sulfate (18), and 5-sitosten-3 $\beta$-ol sulphate (19) were produced by the diatom Skeletonema marinoi [60]. The cholest-5-ene-3 $\beta$-sulfate sodium (20) was found in the methanol extract of the sea urchin Diadema savignyi [61].

Two derivatives of cholesterol sulfate (21 and 22) were isolated from the tropical marine cucumber Holothuria sp. [62], and two derivatives of cholestanol sulfates (23 and 24) and minor sterols (25-29) were detected in the Far Eastern holothurian Eupentacta fraudatrix [57].

An Australian marine sponge Stilopus australis produced a sulfated steroid with the pregnane skeleton (30) [63], and annasterol sulfate (31) was isolated from the Pacific deep-water sponge Poecilastra laminaris, and this compound showed a $\beta$-1,3-glucanase inhibitor [64]. Polyhydroxy-steroid monosulphate (32, for structure see Figure 3 and for for activities see Table 3) was found in the extract of the sponge Toxadocia zumi [65]. Rare mono sulfate steroid with the sulfate group in $2 \beta$-position (33) was isolated from the sponge Echinoclathria suhispida collected from the Japan Sea near the coast of Japan [66]. The Malaysian sponge Haliclona sp. from an Indo-Pacific has yielded haliclostanone sulphate (34) [67]. Cytotoxic steroid (35) containing a sulfate group in $6 \alpha$-position was found in the sponge Dysidea fragilis collected from the lagoon of Venice, Italy [68]. A sulfated steroid called apheloketotriol (36) was isolated from a Far Eastern sponge Aphelasterias japonica [69], and acanthosterol E (37) was found in the sponge Acanthodendrilla sp. containing sulfate group in 6-position [70].

Rare mono sulfate (38) containing a sulfate group in 16-position was found in starfish Luidia clathrata (family Luidiidae) [71], although the other 3-monosulfate (39) was isolated from Far Eastern starfish Luidia quinaria (Japan Sea) [72]. Three sulfated steroidal glycosides (40-42) were isolated from the visceral extract of the cone snail Conus pulicarius. The three new compounds exhibited significant in vitro cytotoxicity ( $\mathrm{GI}_{50}$ values down to $0.49 \mu \mathrm{M}$ ) against the K562 human leukemia cell line [73]. Three sulfated steroid monoglycosides, leptaochotensosides A-C (43-45), and a sulfated polyhydroxylated steroid (33) were isolated from the alcoholic extract of the Far Eastern starfish Leptasterias ochotensis [74]. Leptao- 
chotensoside A (43) demonstrated inhibition of T-47D cell colony formation in a soft agar clonogenic assay at nontoxic doses. In addition, this compound decreased the epidermal growth factor induced colony formation of mouse epidermal JB6-C141 cells. The cancer preventive action of (43) is realized through regulation of the mitogen-activated protein kinase signaling pathway.
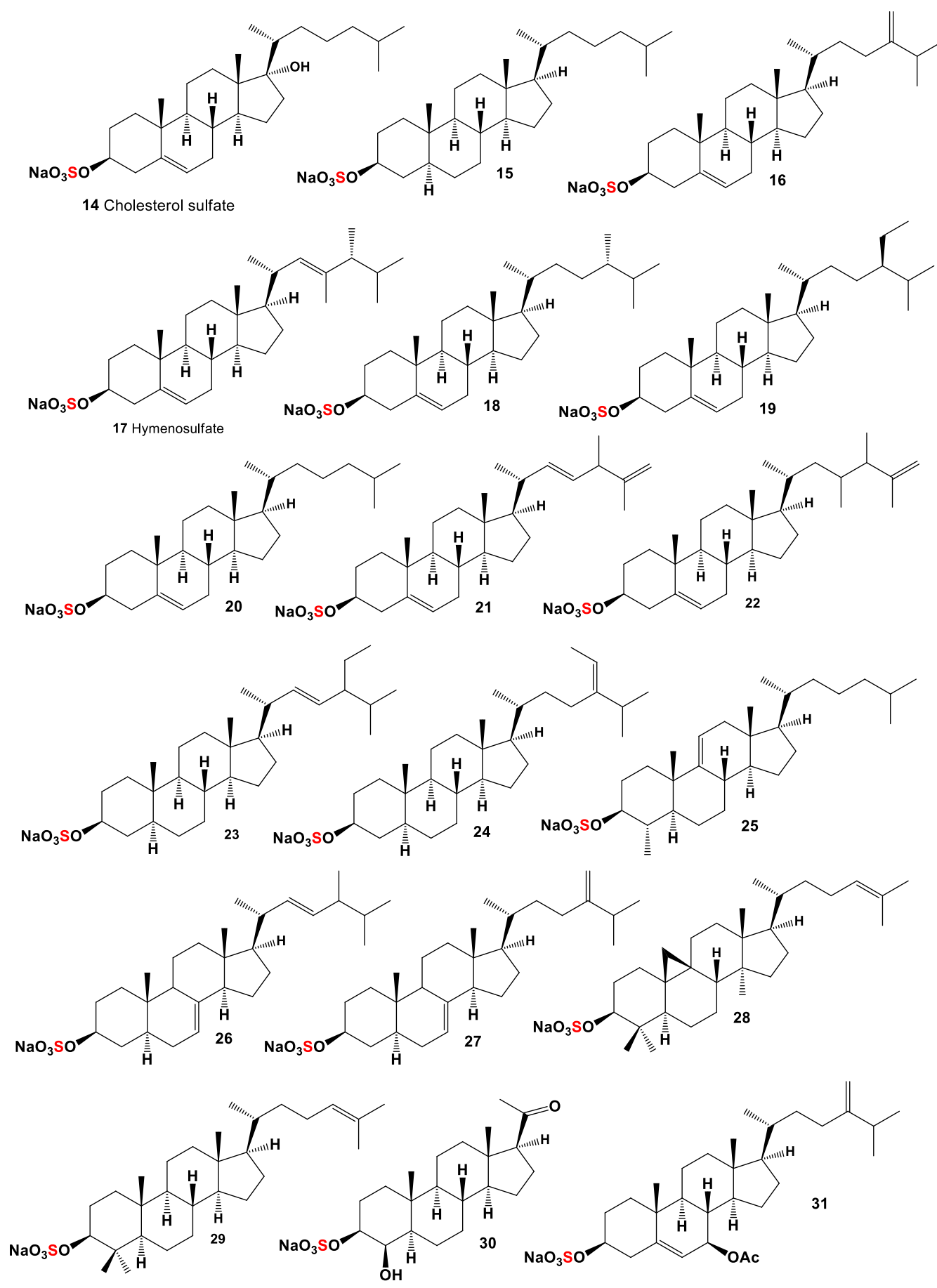

Figure 2. Mono sulfated steroids are derived from marine sources, and their pharmacological profile is shown in Table 2. 

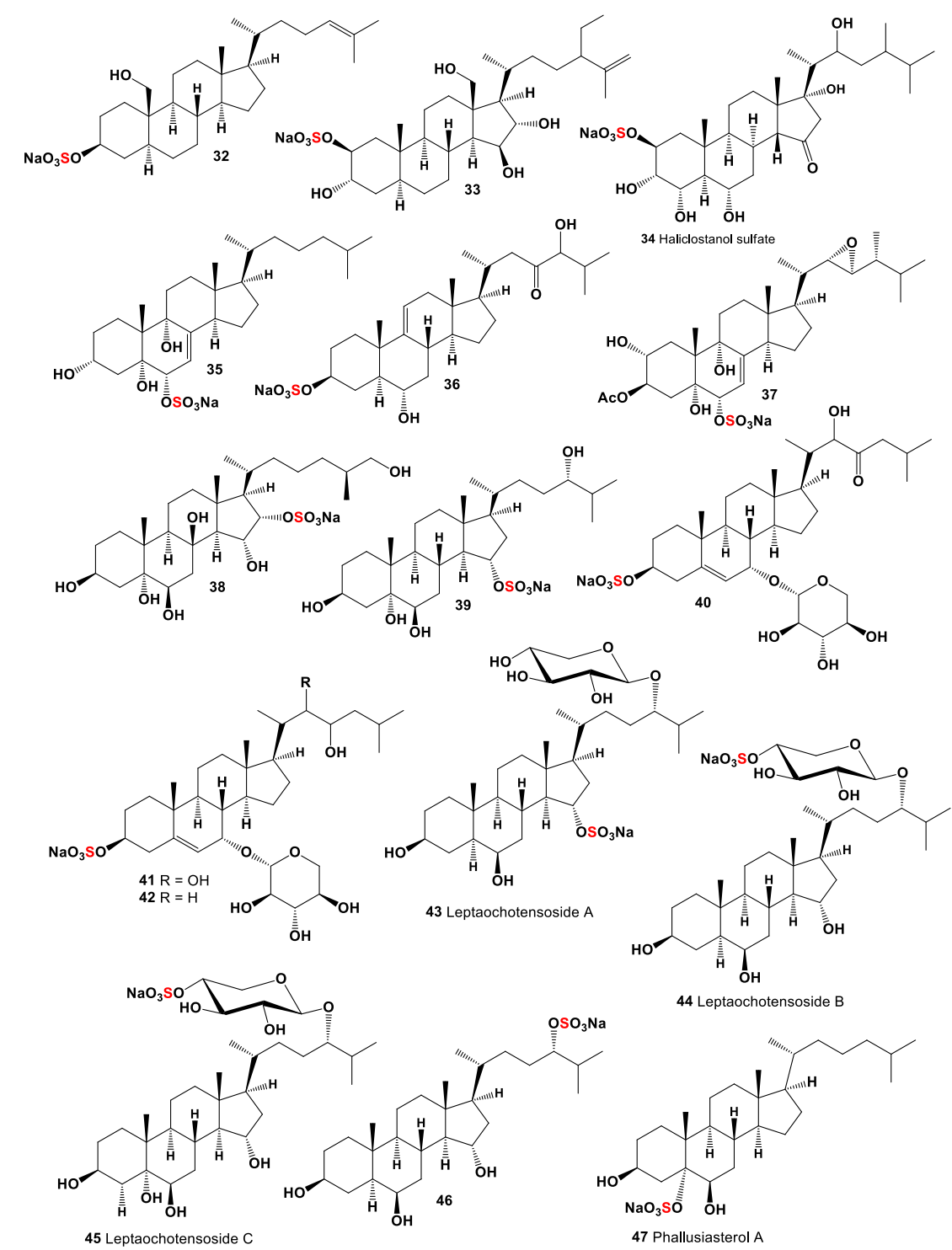

Figure 3. Mono sulfated steroids are derived from marine sources, and their pharmacological profile is shown in Table 3.

Table 3. Biological activities of mono sulfated steroids.

\begin{tabular}{|c|c|c|c|}
\hline No. & Antitumor \& Related Activity, (Pa) * & Violation of Lipid Metabolism, $(\mathrm{Pa})$ * & Additional Predicted Activity, $(\mathbf{P a}) *$ \\
\hline \multirow{3}{*}{32} & Antineoplastic (0.845) & Anti-hypercholesterolemic (0.895); & Hepatoprotectant (0.933) \\
\hline & Chemopreventive (0.834) & Cholesterol synthesis inhibitor (0.776); & Biliary tract disorders treatment $(0.895)$ \\
\hline & Apoptosis agonist (0.826); & Atherosclerosis treatment $(0.712)$ & Wound-healing agent (0.885) \\
\hline \multirow{2}{*}{33} & Chemopre & ciloies & Hep \\
\hline & Antineoplastic (0.805); & Atherosclerosis treatment $(0.561)$ & Antiinflammatory (0.832) \\
\hline \multirow{3}{*}{34} & Antineoplastic (0.830) & Athero & Hepatoprotectant (0.968) \\
\hline & Apoptosis agonist (0.792) & Cholesterol synthesis inhibitor (0.682); & Anti-inflammatory $(0.817)$ \\
\hline & Chemopreventive (0.783) & & Biliary tract disorders treatment $(0.704)$; \\
\hline \multirow{2}{*}{35} & Chemopreventive (0.777) & Anti-hyl & Anti-ischemic, cerebral (0.850) \\
\hline & Antineoplastic (0.779) & Cholesterol synthesis inhibitor (0.717) & Biliary tract disorders treatment $(0.728)$ \\
\hline \multirow{2}{*}{36} & Chemopreventive (0.821) & Cholesterol synthesis inhibitor (0.727) & Biliary tract disorders treatment $(0.833)$ \\
\hline & Antineoplastic (0.765) & Anti-hypercholesterolemic (0.671) & Wound-healing agent (0.794) \\
\hline 37 & Antineoplastic (0.829) & Cholesterol synthesis inhibitor (0.618) & Anti-ischemic, cerebral (0.785) \\
\hline 38 & Antineoplastic (0.813) & Atherosclerosis treatment $(0.629)$ & Biliary tract disorders treatment $(0.639)$ \\
\hline 39 & Antineoplastic (0.823) & Atherosclerosis treatment $(0.715)$ & Biliary tract disorders treatment $(0.931)$ \\
\hline
\end{tabular}


Table 3. Cont.

\begin{tabular}{|c|c|c|c|}
\hline No. & Antitumor \& Related Activity, (Pa)* & Violation of Lipid Metabolism, (Pa) * & Additional Predicted Activity, $(\mathrm{Pa}) *$ \\
\hline \multirow{2}{*}{40} & Chemopreventive (0.924) & Anti-hypercholesterolemic (0.926) & Wound-healing agent (0.953) \\
\hline & Antineoplastic (0.837) & Atherosclerosis treatment $(0.671)$ & Hepatoprotectant $(0.925)$ \\
\hline \multirow{2}{*}{41} & Antineoplastic (0.854) & Anti-hypercholesterolemic (0.902) & Wound-healing agent (0.963) \\
\hline & Apoptosis agonist $(0.790)$ & Atherosclerosis treatment $(0.675)$ & Hepatoprotectant $(0.915)$ \\
\hline \multirow{2}{*}{42} & Chemopreventive (0.918) & Anti-hypercholesterolemic (0.942) & Wound-healing agent (0.975) \\
\hline & Antineoplastic (0.806) & Cholesterol synthesis inhibitor (0.712) & Hepatoprotectant $(0.915)$ \\
\hline \multirow{3}{*}{43} & & Anti-hypercholesterolemic (0.901) & Wound-healing agent (0.980) \\
\hline & Chemopreventive (0.935) & Atherosclerosis treatment $(0.685)$ & Hepatoprotectant (0.972) \\
\hline & & & Biliary tract disorders treatment $(0.958)$ \\
\hline \multirow{2}{*}{44} & Chemopreventive (0.922) & Anti-hypercholesterolemic (0.887) & Wound-healing agent (0.977) \\
\hline & Antineoplastic (0.841) & Atherosclerosis treatment $(0.679)$ & Hepatoprotectant (0.965) \\
\hline \multirow{2}{*}{45} & Chemopreventive (0.931) & Anti-hypercholesterolemic (0.716) & Hepatoprotectant (0.893) \\
\hline & Antineoplastic $(0.861)$ & Atherosclerosis treatment $(0.704)$ & Wound-healing agent (0.887) \\
\hline 46 & Antineoplastic (0.831) & Anti-hypercholesterolemic (0.782) & Wound-healing agent (0.888) \\
\hline 47 & Chemopreventive (0.860) & Anti-hypercholesterolemic (0.850) & Wound-healing agent (0.861) \\
\hline
\end{tabular}

* Only activities with $\mathrm{Pa}>0.5$ are shown.

A rare sulfated steroid at position 5, named phallusiasterol A (47), was isolated from the Mediterranean ascidian Phallusia fumigate [75]. A polyhydroxylated sterol called asterosaponin P2 (48, for structure see Figure 4 and for activities see Table 4), with the sulfate group only in the side chain, isolated from the Far-Eastern starfish Patiria (Asterina) pectinifera [76], exhibited activity against HSV-1 [77].

Table 4. Biological activities of mono-, di-, and poly-sulfated steroids.

\begin{tabular}{|c|c|c|c|}
\hline No. & Antitumor \& Related Activity, (Pa)* & Violation of Lipid Metabolism, $(\mathrm{Pa})$ * & Additional Predicted Activity, (Pa) * \\
\hline \multirow{2}{*}{48} & Chemopreventive (0.913) & Anti-hypercholesterolemic (0.825) & Hepatoprotectant (0.924) \\
\hline & Antineoplastic (0.844) & Cholesterol synthesis inhibitor (0.678) & Biliary tract disorders treatment $(0.727)$ \\
\hline 49 & Antineoplastic (0.716) & Anti-hypercholesterolemic (0.865) & Biliary tract disorders treatment $(0.794)$ \\
\hline 50 & Antineoplastic (0.686) & Anti-hypercholesterolemic (0.679) & Hepatoprotectant (0.653) \\
\hline 51 & Antineoplastic (0.626) & Cholesterol antagonist $(0.820)$ & Anti-inflammatory (0.614) \\
\hline 52 & Antineoplastic (0.691) & Cholesterol antagonist (0.934) & Antifungal (0.696) \\
\hline 53 & Antineoplastic (0.874) & Anti-hypercholesterolemic (0.697) & Anti-inflammatory (0.718) \\
\hline 54 & Antineoplastic (0.849) & Atherosclerosis treatment $(0.748)$ & Anti-inflammatory (0.777) \\
\hline 55 & Antineoplastic (0.869) & Autoimmune disorders treatment $(0.762)$ & Angiogenesis inhibitor (0.926) \\
\hline 56 & Antineoplastic (0.796) & Atherosclerosis treatment $(0.646)$ & Anti-inflammatory $(0.811)$ \\
\hline \multirow{3}{*}{57} & Antineoplastic (0.836) & Atherosclerosis treatment $(0.684)$ & Biliary tract disorders treatment $(0.928)$ \\
\hline & Chemopreventive (0.712) & Cholesterol synthesis inhibitor $(0.656)$ & Hepatic disorders treatment $(0.889)$ \\
\hline & Apoptosis agonist (0.649) & Anti-hypercholesterolemic (0.617) & Wound-healing agent $(0.888)$ \\
\hline 58 & Antineoplastic (0.788) & Cholesterol synthesis inhibitor (0.755) & Biliary tract disorders treatment $(0.843)$ \\
\hline 59 & Antineoplastic (0.793) & Atherosclerosis treatment $(0.636)$ & Biliary tract disorders treatment $(0.713)$ \\
\hline 60 & Antineoplastic (0.782) & Cholesterol synthesis inhibitor $(0.671)$ & Wound-healing agent (0.933) \\
\hline 61 & Antineoplastic (0.820) & Cholesterol synthesis inhibitor (0.734) & Wound-healing agent (0.942) \\
\hline 62 & Antineoplastic (0.711) & Cholesterol synthesis inhibitor (0.696) & Biliary tract disorders treatment $(0.963)$ \\
\hline 63 & Antineoplastic (0.764) & Atherosclerosis treatment $(0.684)$ & Biliary tract disorders treatment $(0.957)$ \\
\hline 64 & Chemopreventive (0.948) & Cholesterol synthesis inhibitor (0.562) & Hepatoprotectant (0.915) \\
\hline 65 & Antineoplastic (0.729) & Cholesterol synthesis inhibitor (0.572) & Biliary tract disorders treatment $(0.835)$ \\
\hline 66 & Antineoplastic (0.734) & Cholesterol synthesis inhibitor (0.661) & Biliary tract disorders treatment $(0.725)$ \\
\hline
\end{tabular}


Table 4. Cont.

\begin{tabular}{|c|c|c|c|}
\hline No. & Antitumor \& Related Activity, (Pa) * & Violation of Lipid Metabolism, $(\mathrm{Pa})$ * & Additional Predicted Activity, $(\mathrm{Pa})$ * \\
\hline 67 & Antineoplastic (0.790) & Cholesterol synthesis inhibitor (0.655) & Wound-healing agent (0.812) \\
\hline 68 & Antineoplastic (0.868) & Atherosclerosis treatment $(0.645)$ & Hepatoprotectant (0.918) \\
\hline 69 & Antineoplastic $(0.868)$ & Atherosclerosis treatment $(0.645)$ & Hepatoprotectant (0.918) \\
\hline 70 & $\begin{array}{c}\text { Antineoplastic }(0.748) \\
\text { Chemopreventive }(0.692)\end{array}$ & $\begin{array}{l}\text { Cholesterol synthesis inhibitor }(0.688) \\
\text { Atherosclerosis treatment }(0.664)\end{array}$ & $\begin{array}{c}\text { Biliary tract disorders treatment }(0.943) \\
\text { Hepatic disorders treatment }(0.934)\end{array}$ \\
\hline 71 & $\begin{array}{c}\text { Antineoplastic (0.767) } \\
\text { Chemopreventive (0.704) }\end{array}$ & $\begin{array}{l}\text { Cholesterol synthesis inhibitor }(0.696) \\
\text { Atherosclerosis treatment }(0.665)\end{array}$ & $\begin{array}{l}\text { Biliary tract disorders treatment }(0.963) \\
\text { Hepatic disorders treatment }(0.934) ;\end{array}$ \\
\hline
\end{tabular}

* Only activities with $\mathrm{Pa}>0.5$ are shown.

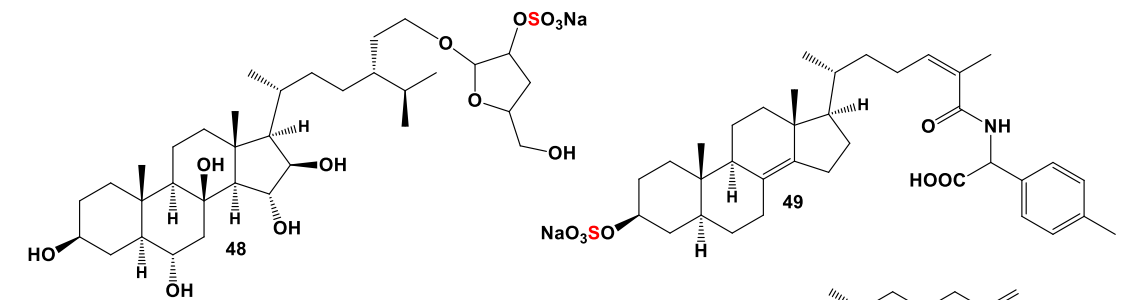

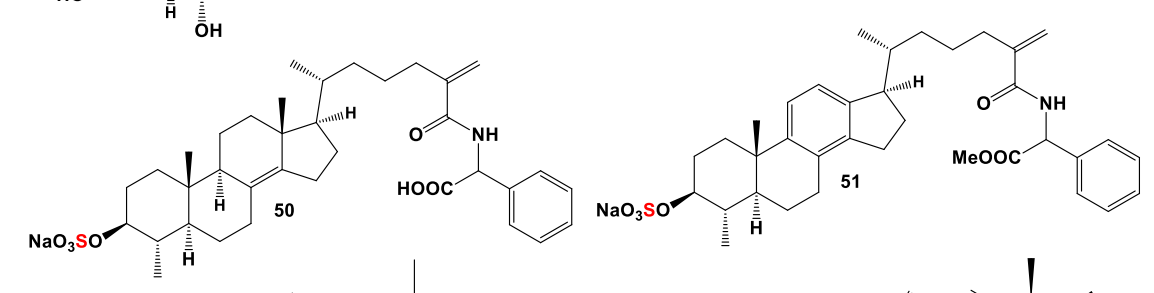

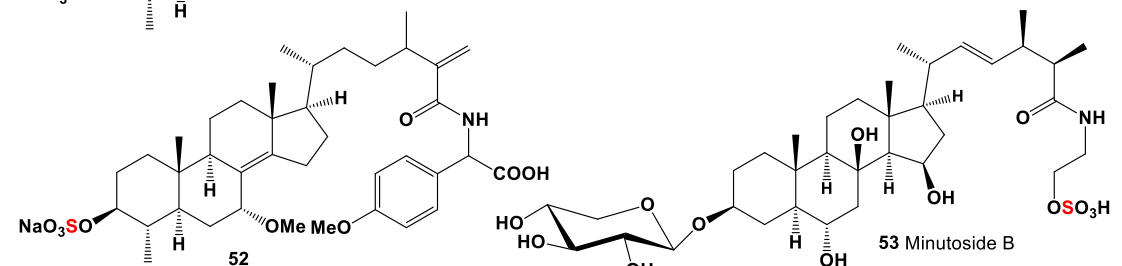

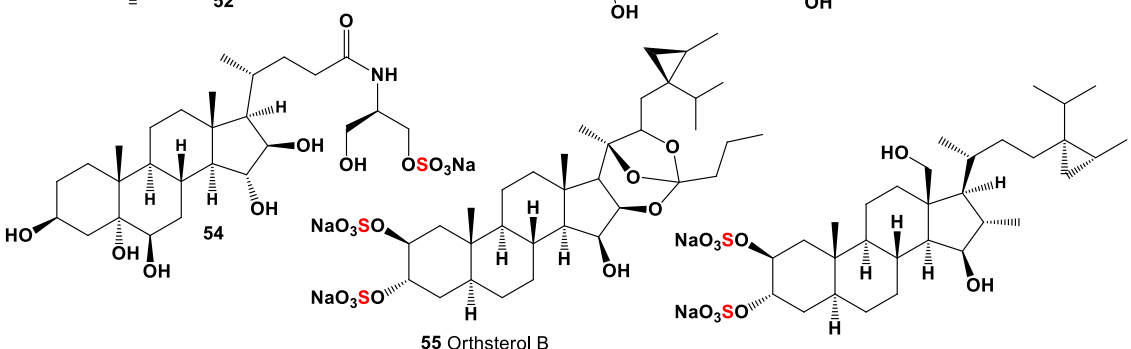

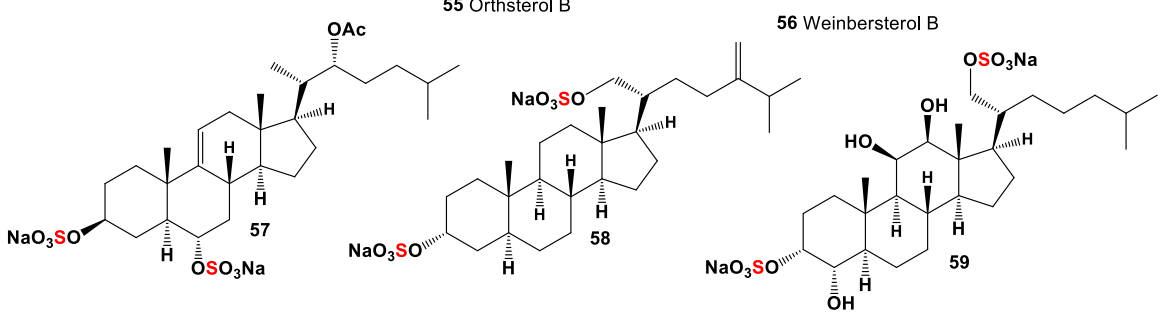

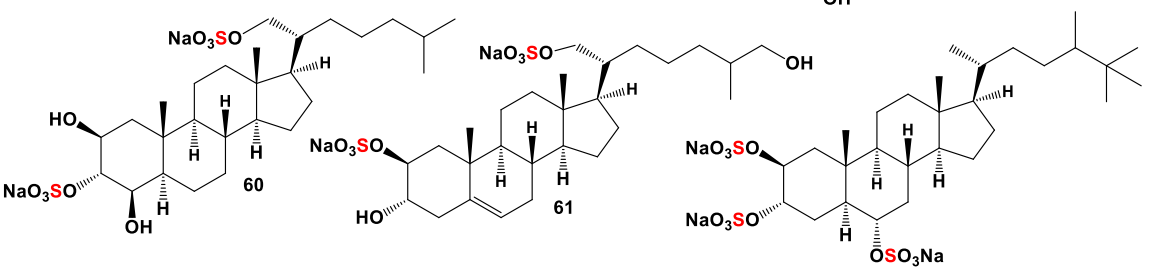

62 Halistanol sulfate

Figure 4. Mono- and poly-sulfated steroids derived from marine sources, and their pharmacological profile, are shown in Table 4. 
A series of sulfated steroid-containing amide fragments (49-54) was detected in marine sponges and echinoderms. Thus, starfish, Styracaster caroli, which was collected at a depth of $2000 \mathrm{~m}$ between the islands of Thio and Lifou (New Caledonia), contained unique polyhydroxylated steroids in water-acetone extract (49 and 50) [78]. The same steroids (49-52 and 54) were found in the sponge Polymastia boletiformis [79,80]. Sulfated steroid xyloside, minutoside B (53), has been isolated from the ethanolic extract of the starfish Anasterias minuta. This xyloside exhibited antifungal activity against Cladosporium cucumerinum and Aspergillus flavus [81].

\section{Di- and Poly-Sulfated Steroids Derived from Marine Sources}

Natural di- and poly-sulfates of steroids represent a rare group of bioactive lipids. Their total content in marine organisms is two to three times less than that of steroids containing one sulfate group $[2,16,18,43]$. The antiviral orthoesterol B (55) showed antiviral activity was found in the marine sponge Petrosia weinbergi [82]. Weinbersterol B (56), a sulphated tetrahydroxy steroid with an unprecedented cyclopropane-containing side chain, was isolated from the sponge Petrosia weinbergi. This compound is active in vitro against feline leukemia virus and active in vitro against HIV [83].

Several steroid disulfates were found in starfish and ophiuroids. Thus, compound (57) was isolated from the starfish Tremaster novaecaledonia [84] and from Aphelasterias japonica [85]. Brittle stars that are echinoderms and belong to the class Ophiuroidea produce many active metabolites including plasmalogen lipids, fatty acids, and steroids [86-91]. Sulfated stanols are widely distributed in various representatives in more than 30 species of Ophiuroidea [2,15-17]. Disulphate stanol (58) was first discovered in brittle star Ophioderma longicaudum [92], and another steroid (59) containing an additional hydroxy group at C12 was isolated from O. longicaudum from the Mediterranean Sea $[2,16,17,93]$. The disulfated steroid (60) containing three functional groups in the ring A was isolated from the Antarctic brittle star Ophiosparte gigas [17], and the same steroid also was found in Astroclades exiguus and Amphiophiura ponderosa [94]. Rare sulfated steroid (62), containing sulfate groups in $2 \beta$ - and $21 \alpha$-positions, was detected in extracts from the starfish of the starfish Pteraster tesselatus [95].

Trisulfated polyhydroxysteroids are rare and typical metabolites that are produced by marine sponges and echinoderms $[2,16,18,19,93]$. Halistanol sulphate sodium (63, for structure see Figure 5 and for activities see Table 4), the most widespread sponge steroid sulfate, was discovered from the sponge Halichondria moori by Fusetani and co-workers [96]. Analog of compound (63), halistanol sulfate I sodium (64) was isolated from a marine sponge Halichondria sp. collected at Hachijo-jima Island. The obtained steroid showed inhibitory activity against SIRT $1-3$ with $\mathrm{IC}_{50}$ of $45.9,18.9$, and $21.8 \mu \mathrm{M}$, respectively [97].

A polyhydroxylated sterol derivative called topsensterol B (65) has been isolated from a marine sponge Topsentia sp. collected from the South China Sea. The isolated compound exhibited cytotoxicity against human gastric carcinoma cell line SGC-7901 with an IC 50 value of $8.0 \mu \mathrm{M}$ [98], and topsentiasterol sulphate E (66) was found in extracts of the sponge Spheciospongia sp., collected in the Philippines. This compound inhibited PKCzeta with an $\mathrm{IC}_{50}$ value of $1.21 \mu \mathrm{M}$, and in a cell-based assay also inhibited NF-kappa B activation with $\mathrm{EC}_{50}$ value of $12 \mu \mathrm{M}$ [99].

Representatives of Echinodermata's and other marine and freshwater invertebrates contain very interesting lipid molecules, such as polar lipids and fatty aldehydes [86,100-104]. In addition, two trisulfated steroids have also been found in various types of ophiuroids, so the steroid (67) is isolated from Ophiura sarsi, and another steroid (68) is isolated from Ophiorachna incrassate [105].

Rare sulfated sterol dimers called fibrosterol sulphates A (69) and B (70) were isolated from a Lissodendoryx (Acanthodoryx) fibrosa sponge from Coron Island Palawan, Philippines [99]. Both compounds have inhibited PKC $\zeta$ with $\mathrm{IC}_{50}$ values of 16.4 and $5.6 \mu \mathrm{M}$, respectively [106]. Socotrasterol sulphate (71) was isolated from different sponge species [107], and ophirapsterol sulphate (69) was found in Topsentia ophiraphidites [108]. 


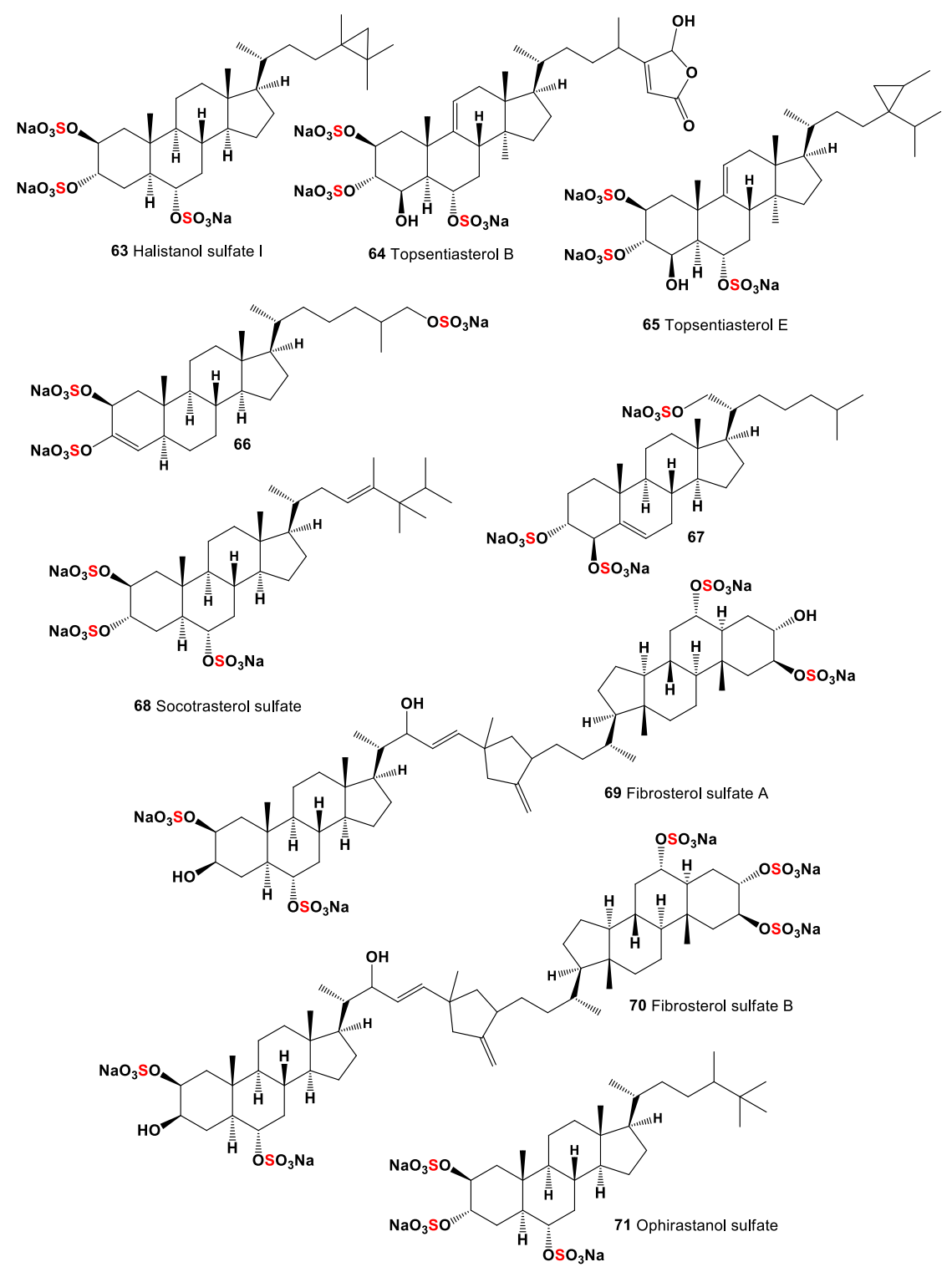

Figure 5. Polysulfated steroids derived from marine sources, and their pharmacological profile is shown in Table 4.

\section{Sulfur-Containing Steroids Derived from Marine and Terrestrial Sources}

A wide variety of chemical structures of steroids and terpenoids was found in extracts of marine sediments, as well as both contemporary and geologically ancient deposits [29,31,109-114]. Aromatic sterols, triterpenoids, and sulfur-containing compounds have been found in marine sediments and crude oil [31-34,115-120].

Until now, there has been no evidence that microorganisms do not participate in the formation of sulfur-containing steroids, but nevertheless, these lipid markers are of great interest for biochemistry, geochemistry, and pharmacology [119-122]. More than 3000 terpenoids and other lipid molecules have been isolated from sedimentary rocks and marine sediments - this is an established fact [28,30,33,39-42,111-114]. Sulfur-containing steroids and terpenoids make up the bulk of natural compounds that are isolated from ancient sediments, petroleum, deposits, and marine sediments [111-114,117,123-127].

An unusual pregnane-type steroid called krempene A (72, structures are shown in Figure 6 and activity showed in Table 5) was isolated from the marine soft coral Cladiella krempfi. The isolated compound contains a very unusual structural motif, with a hexacyclic oxadithiino unit fused to the steroidal ring A [128]. 
<smiles>C=C[C@H]1CC[C@H]2[C@@H]3CC[C@H]4CC(=O)[C@@H]5OCSS[C@H]5[C@]4(C)[C@H]3CC[C@@]21C</smiles>

72 Krempene A

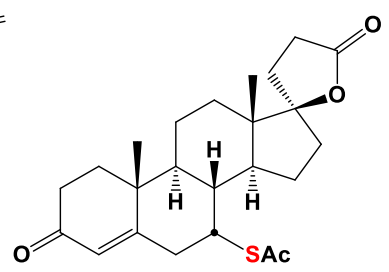

73 Spironolactone<smiles></smiles>

74

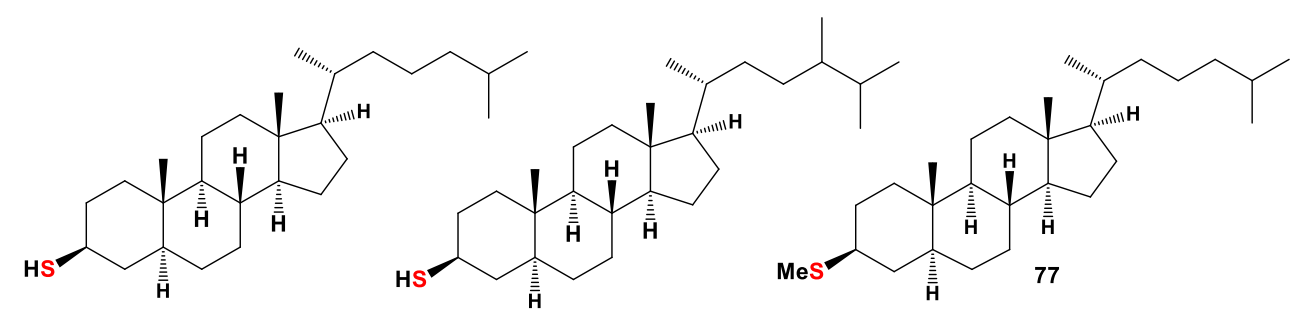

75 Thiocholestane

76 Thiocampestane

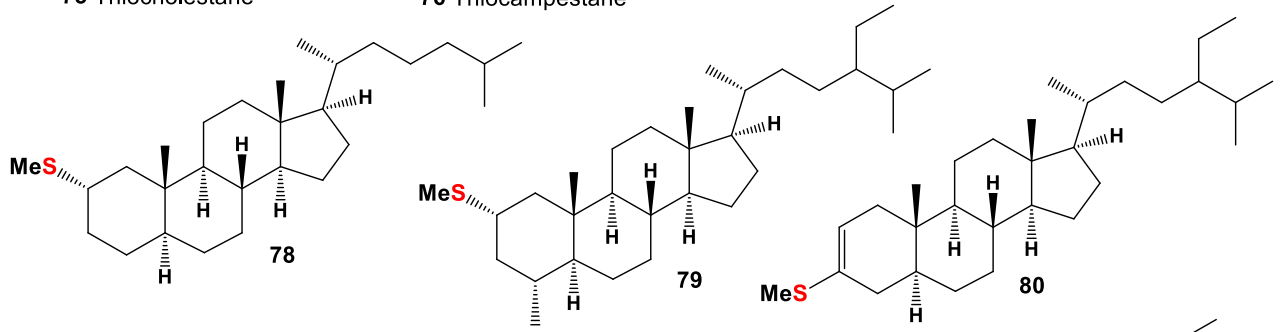

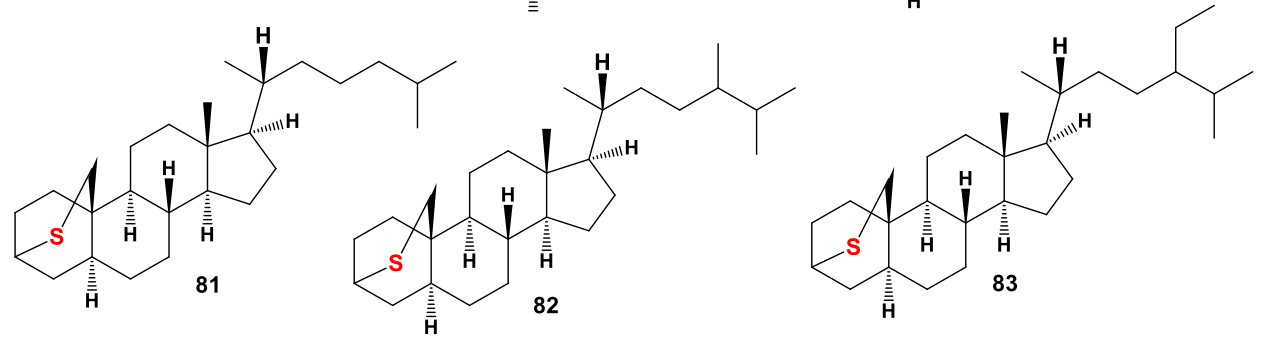

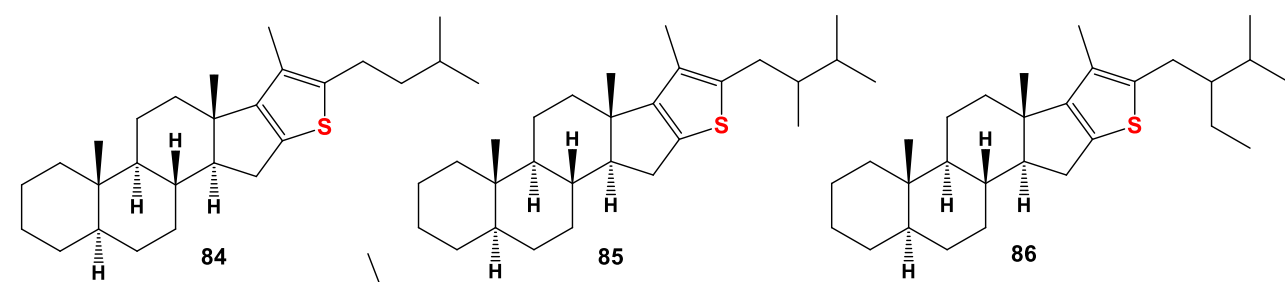

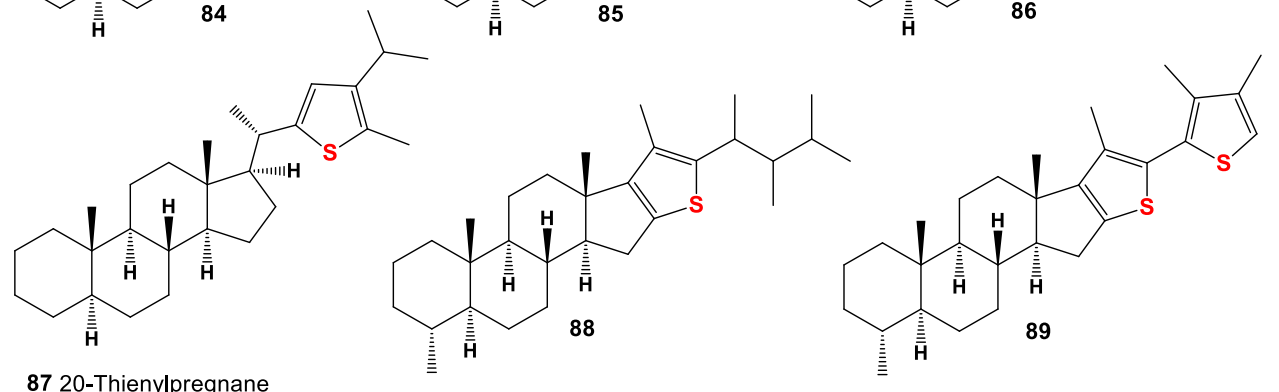

Figure 6. Sulfur-containing steroids and triterpenoids derived from marine invertebrates, sediments, crude oil, and other sources, and their pharmacological profile is shown in Table 5.

The 3-(3-oxo-7 $\alpha$-methylsulfinyl-6 $\beta, 17 \beta$-dihydroxy-4-androsten-17 $\alpha$-y1)-propionic acid $\gamma$-lactone called spironolactone (73) has been found and isolated in the human urine by Karim and Brown in 1972 [129]. The physiological properties and biogenesis of spironolactone in humans are well described in several reviews [130-133].

$5 \alpha$-Androstan-16-one, cyclic ethylene mercaptole (74), was present in the ethanol extract of the whole plant of Andrographis echioides [134]. Two thiosteranes, $3 \beta$-thio- $5 \alpha$ - 


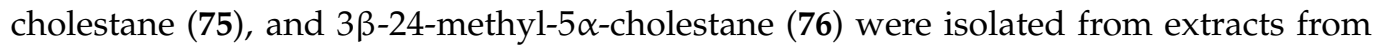
Marrakech activated sludge, which is formed from the leaves and the date palm of the date palm $[135,136]$.

Table 5. Biological activities of sulfur-containing steroids.

\begin{tabular}{|c|c|c|c|}
\hline No. & Antitumor \& Related Activity, $(\mathrm{Pa})$ * & Specific Activities, $(\mathrm{Pa}) *$ & Additional Predicted Activity, $(\mathrm{Pa})$ * \\
\hline 72 & Antineoplastic (0.842) & $\begin{array}{c}\text { Erythropoiesis stimulant }(0.722) \\
\text { Prostate disorders treatment }(0.688)\end{array}$ & $\begin{array}{c}\text { Anti-eczematic }(0.773) \\
\text { Anti-seborrheic }(0.733) \\
\text { Anti-psoriatic }(0.658)\end{array}$ \\
\hline 73 & Antineoplastic (0.868) & $\begin{array}{c}\text { Diuretic }(0.991) \\
\text { Anti-hyperaldosteronism }(0.963) \\
\text { Antihypertensive }(0.940) \\
\text { Renal disease treatment }(0.934)\end{array}$ & $\begin{array}{c}\text { Cardiotonic }(0.850) \\
\text { Anti-ischemic, cerebral }(0.822) \\
\text { Antiarthritic }(0.741) \\
\text { Antithrombotic }(0.691)\end{array}$ \\
\hline 74 & Antineoplastic (0.824) & Anti-osteoporotic (0.917) & Anti-seborrheic (0.845) \\
\hline 75 & Antineoplastic (0.723) & Prostate disorders treatment $(0.735)$ & Anti-eczematic (0.787) \\
\hline 76 & Antineoplastic (0.736) & Prostate disorders treatment $(0.745)$ & Anti-eczematic (0.813) \\
\hline 77 & Antineoplastic (0.774) & Anesthetic general (0.774) & Anti-eczematic (0.809) \\
\hline 78 & Antineoplastic (0.774) & $\begin{array}{l}\text { Anesthetic general }(0.774) \\
\text { Respiratory analeptic }(0.675)\end{array}$ & $\begin{array}{l}\text { Anti-eczematic }(0.809) \\
\text { Anti-psoriatic }(0.686)\end{array}$ \\
\hline 79 & $\begin{array}{l}\text { Antineoplastic }(0.773) \\
\text { Antimetastatic }(0.682)\end{array}$ & Anti-osteoporotic (0.683) & $\begin{array}{l}\text { Anti-eczematic }(0.776) \\
\text { Anti-psoriatic }(0.643)\end{array}$ \\
\hline 80 & $\begin{array}{c}\text { Antineoplastic }(0.729) \\
\text { Apoptosis agonist }(0.680)\end{array}$ & Anti-osteoporotic (0.789) & Anti-eczematic (0.782) \\
\hline 81 & Antineoplastic (0.681) & Anti-osteoporotic (0.730) & Anti-eczematic (0.798) \\
\hline 82 & $\begin{array}{c}\text { Antineoplastic }(0.664) \\
\text { Apoptosis agonist }(0.624)\end{array}$ & Anti-osteoporotic (0.742) & $\begin{array}{l}\text { Anti-eczematic }(0.771) \\
\text { Anti-psoriatic }(0.619)\end{array}$ \\
\hline 83 & Antineoplastic (0.700) & Anti-osteoporotic (0.744) & Anti-eczematic (0.766) \\
\hline 84 & & Anesthetic general (0.761) & Anti-seborrheic (0.823) \\
\hline 85 & Antineoplastic (0.618) & Prostate disorders treatment $(0.667)$ & Anti-seborrheic (0.817) \\
\hline 86 & & Prostate disorders treatment $(0.652)$ & Anti-seborrheic (0.810) \\
\hline 87 & Antineoplastic (0.756) & Antiallergic (0.785) & $\begin{array}{l}\text { Anti-psoriatic }(0.818) \\
\text { Anti-eczematic }(0.756)\end{array}$ \\
\hline 88 & Antineoplastic (0.658) & Prostate disorders treatment $(0.669)$ & $\begin{array}{c}\text { Dermatologic (0.692) } \\
\text { Anti-eczematic (0.678) }\end{array}$ \\
\hline 89 & Antineoplastic (0.730) & Anti-osteoporotic (0.696) & \\
\hline
\end{tabular}

* Only activities with $\mathrm{Pa}>0.5$ are shown.

Four thio-5 $\alpha$-cholestane derivatives (77-80) were isolated from the polar fractions of the organic matter of both oils and sediment extracts, which were collected in various parts of the world, in Europe, North America, and China [113,114,137-140].

Many authors have attempted to investigate the organic matter generated in hypersaline environments, including both sea and salt seas, and a warm eutrophic salt lake in Southern California, where sulfur-containing compounds have been found and isolated, including unusual thiosterols (81-87), and their unusual chemical structures have been established [113,114,124-127]. Interesting data were obtained by Chinese scientists who studied the sulfur-rich heavy oils in Jinxian Sag, Bohai Bay Basin, northern China, and found high abundances of organic sulfur compounds, including a series of short-chain steranes (C21-26), unusual short chainlanostanes (C24-25), 4-methyl steranes (C22-23), 4,4-dimethyl steranes (C22-24), and androstanes (C19-20), accompanied by high-molecularweight analogues, regular steranes, 4-methyl steranes, and 4,4-dimethyl steranes, as well as sulfur containing steroids (80,88-92, for structure see Figures 6 and 7 and for activities 
see Tables 5 and 6). The authors believe that the occurrence of abundant sulfur-containing steroids was the result of extensive sulfurization during early diagenetic stages, because many more double bonds, hydroxyl groups, and carbonyl groups exist in sterols and steranes, which are prone to attack by inorganic sulfur [141].

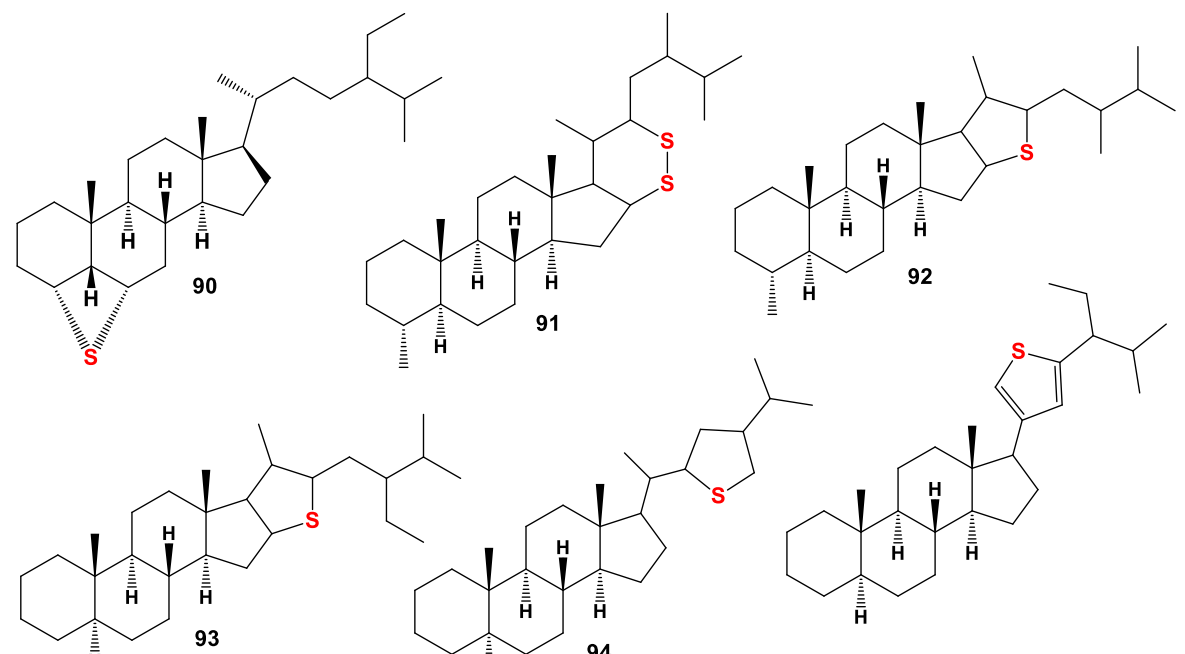

95 17-Thienylandrostane

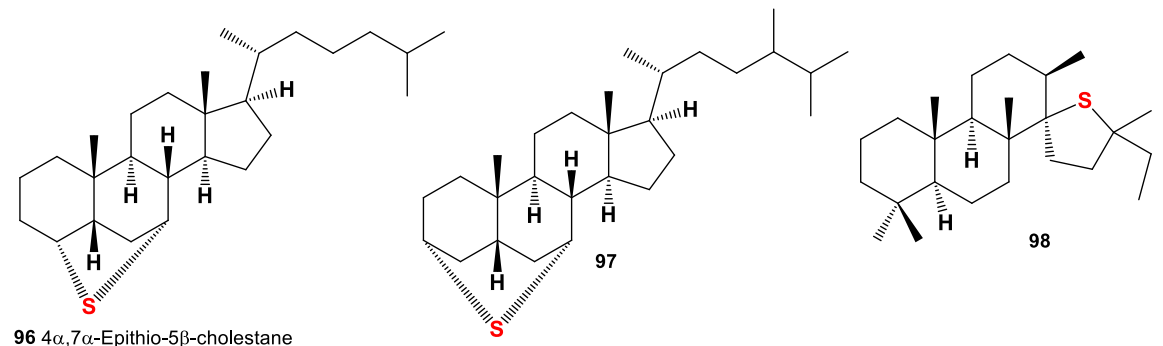

$964 \alpha, 7 \alpha$-Epithio- $5 \beta$-cholestane

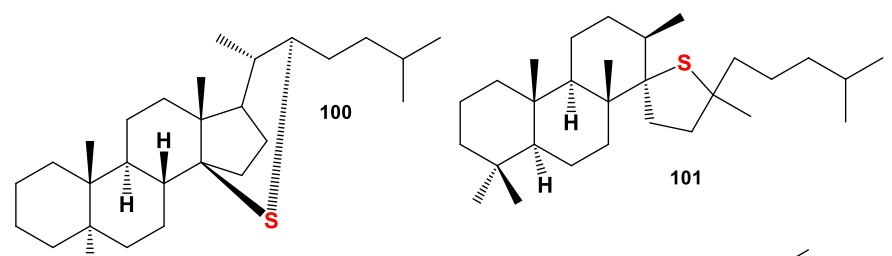<smiles>CC1(C)CCCC2(C)[C@H]3CCC4CCCC[C@H]4C3CC[C@@H]12</smiles><smiles>C1CCC1</smiles><smiles>CCCCC(C)(C)C</smiles><smiles>CCCC(C)C(C)C(C)CC(C)C(C)C</smiles>

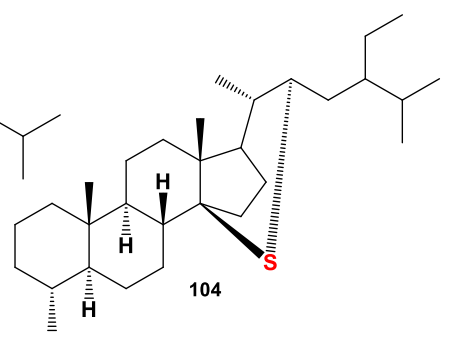<smiles>C=C(CCCC1(C)CCCC(C)S1)[C@H]1CCC2[C@@]3(C)CCC[C@H](C)[C@@H]3CC[C@@]21C</smiles><smiles>CCCCCCCCC</smiles>

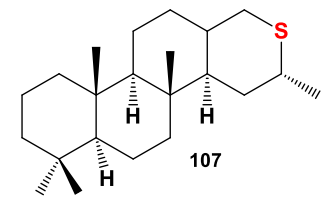

Figure 7. Sulfur-containing steroids and triterpenoids derived from marine sediments, crude oil, and other sources, and their pharmacological profile is shown in Table 6. 
Table 6. Biological activities of sulfur-containing steroids.

\begin{tabular}{|c|c|c|c|}
\hline No. & Antitumor \& Related Activity, $(\mathbf{P a})^{*}$ & Specific Activities, $(\mathbf{P a})^{*}$ & Additional Predicted Activity, $(\mathrm{Pa})$ * \\
\hline 90 & Antineoplastic (0.740) & Anti-osteoporotic (0.750) & Anti-eczematic (0.824) \\
\hline 91 & Antineoplastic (0.773) & Hepatic disorders treatment $(0.676)$ & Anti-seborrheic (0.692) \\
\hline 92 & Antineoplastic (0.658) & Antiprotozoal (Plasmodium) (0.627) & Anti-seborrheic (0.656) \\
\hline 93 & & Antihypertensive (0.705) & Anti-seborrheic (0.809) \\
\hline 94 & & Hepatic disorders treatment $(0.728)$ & Anti-eczematic (0.736) \\
\hline 95 & & Anesthetic general (0.762) & Anti-seborrheic (0.787) \\
\hline 96 & & Anti-osteoporotic (0.641) & Anti-eczematic (0.840) \\
\hline 97 & & Atherosclerosis treatment $(0.680)$ & $\begin{array}{l}\text { Anti-eczematic (0.808) } \\
\text { Anti-psoriatic }(0.649)\end{array}$ \\
\hline 98 & $\begin{array}{l}\text { Apoptosis agonist }(0.947) \\
\text { Antineoplastic }(0.862)\end{array}$ & Inflammatory bowel disease treatment $(0.842)$ & $\begin{array}{c}\text { Anti-eczematic }(0.898) \\
\text { Anti-psoriatic }(0.828) \\
\text { Septic shock treatment }(0.619)\end{array}$ \\
\hline 99 & $\begin{array}{l}\text { Apoptosis agonist }(0.947) \\
\text { Antineoplastic }(0.869)\end{array}$ & Inflammatory bowel disease treatment $(0.842)$ & $\begin{array}{c}\text { Anti-eczematic }(0.898) \\
\text { Anti-psoriatic }(0.828) \\
\text { Septic shock treatment }(0.619)\end{array}$ \\
\hline 100 & $\begin{array}{l}\text { Apoptosis agonist }(0.929) \\
\text { Antineoplastic }(0.822)\end{array}$ & Antipruritic (0.590) & $\begin{array}{l}\text { Anti-eczematic (0.859) } \\
\text { Anti-psoriatic }(0.798)\end{array}$ \\
\hline 101 & & Anti-obesity (0.750) & $\begin{array}{l}\text { Anti-seborrheic }(0.797) \\
\text { Anti-eczematic }(0.696)\end{array}$ \\
\hline 102 & & Anti-obesity (0.616) & $\begin{array}{l}\text { Anti-seborrheic }(0.782) \\
\text { Anti-eczematic }(0.691)\end{array}$ \\
\hline 103 & & Anti-obesity (0.768) & $\begin{array}{l}\text { Anti-seborrheic }(0.791) \\
\text { Anti-eczematic }(0.687)\end{array}$ \\
\hline 104 & & Antihypertensive (0.650) & $\begin{array}{l}\text { Anti-eczematic (0.719) } \\
\text { Anti-seborrheic }(0.640)\end{array}$ \\
\hline 105 & $\begin{array}{l}\text { Apoptosis agonist }(0.933) \\
\text { Antineoplastic }(0.872)\end{array}$ & Dermatologic (0.781) & $\begin{array}{l}\text { Anti-eczematic (0.847) } \\
\text { Anti-psoriatic }(0.822)\end{array}$ \\
\hline 106 & Antineoplastic (0.708) & Antihypertensive (0.655) & Anti-seborrheic (0.676) \\
\hline 107 & Apoptosis agonist (0.649) & Anti-inflammatory (0.626) & Dermatologic (0.639) \\
\hline
\end{tabular}

* Only activities with $\mathrm{Pa}>0.5$ are shown.

Several series of organic sulfur compounds have been identified in several oils and sediment extracts including Rozel Point Oil (Box Elder County, UT, USA, Miocene). Series of isoprenoid thiophenes, isoprenoid thiolanes, isoprenoid bithiophenes, isoprenoid thienylthiolanes, isoprenoid benzothiophenes, 2,5-di-n-alkylthiolanes, 2,6-di-n-alkylthianes and 2,4-di-n-alkyl-benzo(b)thiophenes, and several thiophene and thiolane steranes (84-86, 92, 93 and 95) have been identified [142]. A sulfur-containing sterane, $4 \alpha, 7 \alpha$-epithio-5 $\beta$ cholestane (96), has been identified in a sediment extract from the Miocene Northern Apennines marl (Italy) [143]. Another 3 $\alpha, 7 \alpha$-epithio-24-Me-5 $\beta$-cholestane (97) was isolated from the polar fractions of sediment extracts and a crude oil taken from a Jurfed Darawish oil shale Jordan [144]. C27-C29 homologs have been detected in sediment extracts of three different formations and in one petroleum sample. These sulfur-containing steroids are probably formed by an intramolecular reaction of inorganic sulfides with early diagenetic products of $\Delta 5,7$-sterols.

Several sulfur-containing compounds $(86,92,94,97,99,102$, and 104) were isolated from water-methanol extracts of the organic phase of solutions obtained from treatment with microbial mats, which were deposited in a Lagoona setting, revealing three lithofacie, and limestones with fine-scale parallel laminations, limestones with undulated (stromatolite-type) laminations, and massive limestones. These different lithofacies refer to The Upper Jurassic Calcaires en plaquettes Formation, which is located on the southern 
Jura in France [145]. The triterpenoid thiane (105) was identified from organic matter in the Holocene and latest Pleistocene sediments of the Cariaco Basin, Venezuela [146].

A series of sulfur-containing sterols (98-101, 103, 107, and 108, for structure see Figure 8 and for activities see Table 7) have been characterized in a wide range of sediments, and they were isolated from a sample from Sémecourt (Paris basin, France) [147], and compound (109) was detected in petroleum from Alberta province, Western Canada [148].

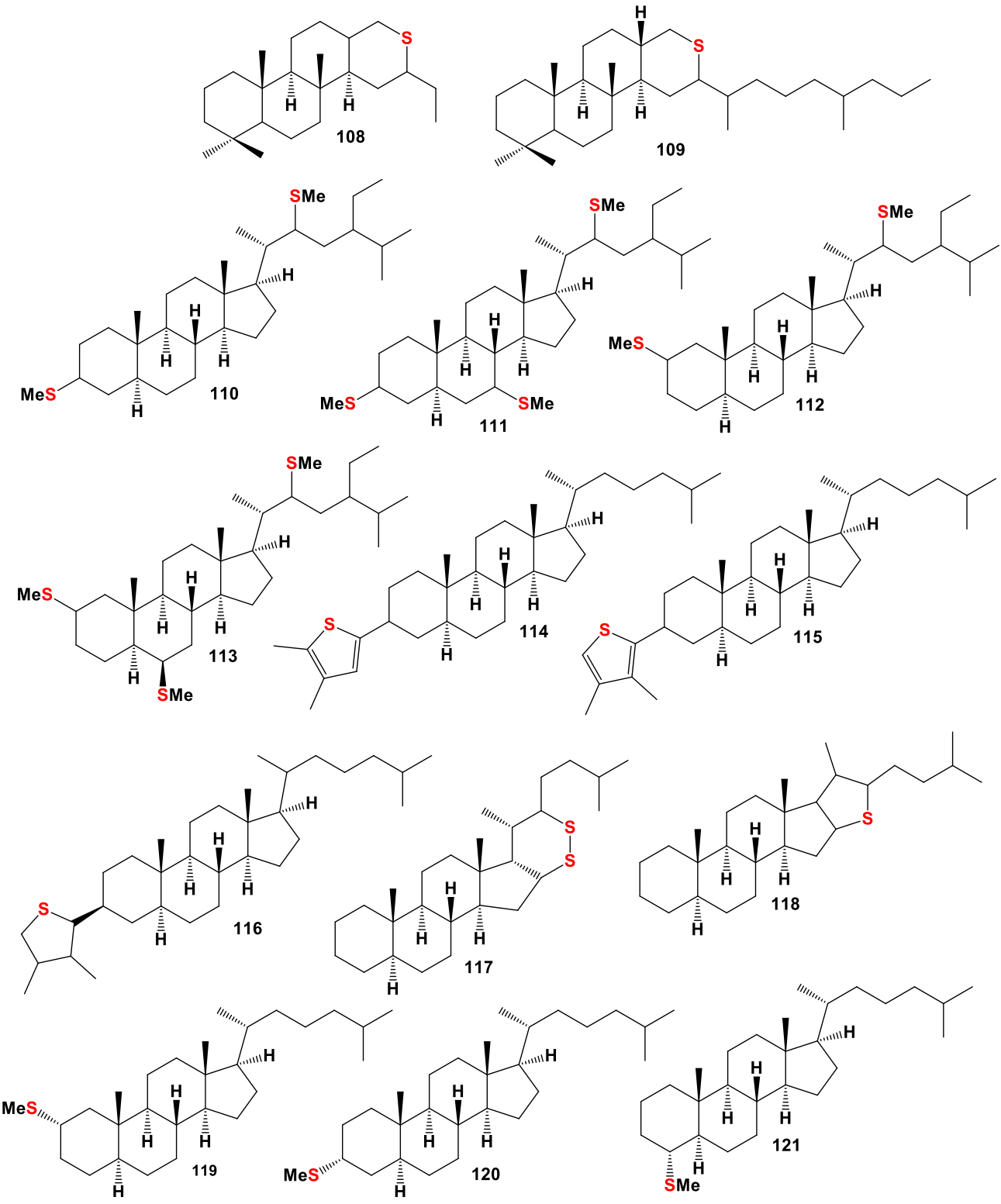

Figure 8. Sulfur-containing steroids and triterpenoids derived from marine sediments, crude oil, and other sources, and their pharmacological profile is shown in Table 7.

Sulfur-containing steroids $(84,85,89,90,117$, and 118) and methylthio-steroids (110-113) were identified by GC-MS in saturate hydrocarbon fractions of heavy oil with a high sulfur content in the Jinxian Sag, Bohai Bay Basin, North China $[139,141]$. Homologous series of 3-n-alkyl-1,2-dithianes and 3-n-alkyl-6-methyl-1,2-di-thianes, including (91, 106, and 117), have been identified in immature sediments [137].

A series of thiophenes with C-3 alkylated steroid carbon skeletons (114-116) have been identified in sediments of the Miocene Monterey Formation (California, USA) and in the Turonian Tarfaya basin (Morocco). Their carbon skeletons were unusual in the sense 
that the alkyl sidechains at C-3 are almost exclusively isopentyl, 3-methylpentyl, and 2,3dimethylbutyl moieties, whilst n-alkyl (pentyl or hexyl) moieties are almost absent [144].

$2 \alpha-, 3 \alpha-$, and $4 \alpha$-Methylthio-steroids (119-121) that were present in the polar fractions of six immature samples (both crude oils and sediment extracts) have been analyzed using S-selective chemolysis methods and analytical pyrolysis [137].

Table 7. Biological activities of sulfur-containing steroids.

\begin{tabular}{|c|c|c|c|}
\hline No. & Antitumor \& Related Activity, $(\mathrm{Pa})$ * & Specific Activities, $(\mathrm{Pa}) *$ & Additional Predicted Activity, $(\mathrm{Pa})$ * \\
\hline 108 & $\begin{array}{l}\text { Antineoplastic }(0.764) \\
\text { Antimetastatic }(0.657)\end{array}$ & Hypolipemic (0.700) & Anti-eczematic (0.766) \\
\hline 109 & Antineoplastic (0.756) & Hepatic disorders treatment $(0.794)$ & Anti-eczematic (0.753) \\
\hline 110 & $\begin{array}{l}\text { Antineoplastic }(0.764) \\
\text { Antimetastatic }(0.657)\end{array}$ & Hypolipemic (0.700) & Anti-eczematic (0.766) \\
\hline 111 & Antineoplastic (0.747) & Hepatic disorders treatment $(0.690)$ & Anti-eczematic (0.739) \\
\hline 112 & Antineoplastic (0.671) & Anti-osteoporotic (0.710) & $\begin{array}{l}\text { Anti-eczematic }(0.808) \\
\text { Anti-psoriatic }(0.669)\end{array}$ \\
\hline 113 & Antineoplastic (0.692) & Anti-osteoporotic (0.687) & Anti-eczematic (0.803) \\
\hline 114 & Antineoplastic (0.702) & Anti-osteoporotic (0.727) & Anti-eczematic (0.816) \\
\hline 115 & Antineoplastic (0.766) & Hepatic disorders treatment $(0.731)$ & Anti-seborrheic (0.836) \\
\hline 116 & Antineoplastic (0.768) & Hepatic disorders treatment $(0.728)$ & Anti-seborrheic (0.844) \\
\hline 117 & Antineoplastic (0.751) & Prostate disorders treatment $(0.776)$ & Anti-eczematic (0.792) \\
\hline 118 & Antineoplastic (0.749) & Prostate disorders treatment $(0.782)$ & Anti-eczematic (0.770) \\
\hline 119 & Antineoplastic (0.834) & Anti-osteoporotic (0.717) & Anti-eczematic (0.806) \\
\hline 120 & Antineoplastic (0.828) & Anti-osteoporotic (0.722) & Anti-eczematic (0.811) \\
\hline 121 & Antineoplastic (0.829) & Anti-osteoporotic (0.720) & Anti-eczematic (0.809) \\
\hline
\end{tabular}

\section{Epithio Steroids}

Semi-synthetic and synthetic epithio steroids represent a rare group of bioactive lipids, since they are hydrophobic molecules insoluble in water, which were not found in nature. Epithio steroids have been reported to possess a variety of cytotoxic activities, and they are widely used as anticancer agents. The thiirane group is an important substance and shows some promising biological activities.

Steroids containing an epithio group in positions 2 and 3 belong to anabolic steroids and are widely known and used in sports medicine and are of great interest for the pharmacology of sports and other aspects of medicine [149-154]. The most widely known are such epithio steroids that are used in sports pharmacology and medicine: epistane $(2 \alpha, 3 \alpha-$ epithio- $17 \alpha$-methyl- $5 \alpha$-androstan-17 $\beta$-ol), epitiostanol ( $2 \alpha, 3 \alpha$-epithio- $5 \alpha$-androstan- $17 \beta$ ol, known as potent anti-estrogenic and antitumor agent), hemapolin $(2 \alpha, 3 \alpha$-epithio$17 \alpha$-methyl-5 $\alpha$-androstan-17 $\beta$-ol), mepitiostane (epitiostanol 17 $\beta$-methoxy-cyclopentyl ether), epivol $(2 \alpha, 3 \alpha$-epithio-17 $\alpha$-methylethio-allo-cholanol), epivol black ( $2,3 \alpha$-epithio-

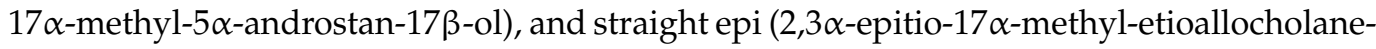
$17 \beta$-ol) $[149,150,152,155-158]$.

2,3-Epithio steroids (122-133, for structure see Figure 9 and for activities see Table 8) belong to a large group of anabolic steroids and are of the greatest interest to pharmacologists and lipidomic networks. Two known 2,3-epithio steroids, such as epitiostanol and epistane methylated prohormone, were both synthesized in the 1960's and used as a treatment for breast cancer, and the second steroid was used to increase lean muscle mass as well as cutting fat [159-162]. The 2,3-epithio steroids have exhibited other specific physiological activities [152]. Several epithio steroids such as two 3,4-epithio steroids, 
$3 \beta, 4 \beta$-epithio- $5 \alpha$-androstan- $17 \beta$-ol (134), and $5 \alpha, 6 \alpha$-epithio cholestan- $3 \beta$-ol (135), $7 \alpha, 8 \beta$ epithio-3 $\beta$-cholesterol (136), $11 \beta, 12 \beta$-epithio- (137), $17 \alpha, 18 \alpha$-epithio- (138) steroids, and an interesting thiirane-containing steroid (139) have been synthesized in different laboratories; however, they had one goal of obtaining a steroid with specific biological activities, for example, an inhibitor of estrogen synthetase, gonadotropin inhibitors, or agents that demonstrate antiseptic, germicidal, fungicidal, or antitumor activities [152,160,162-164].

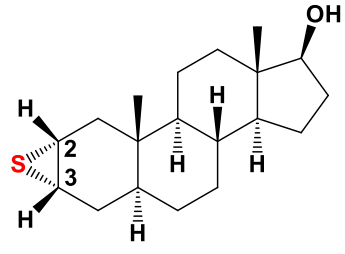

122 Epitiostanol

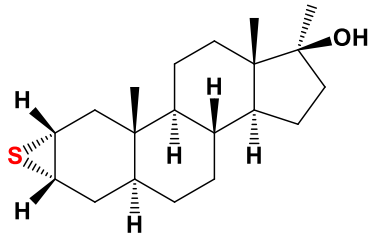

123 Epistane

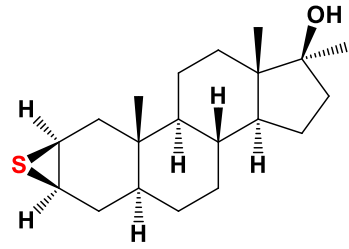

124 Hemapolin

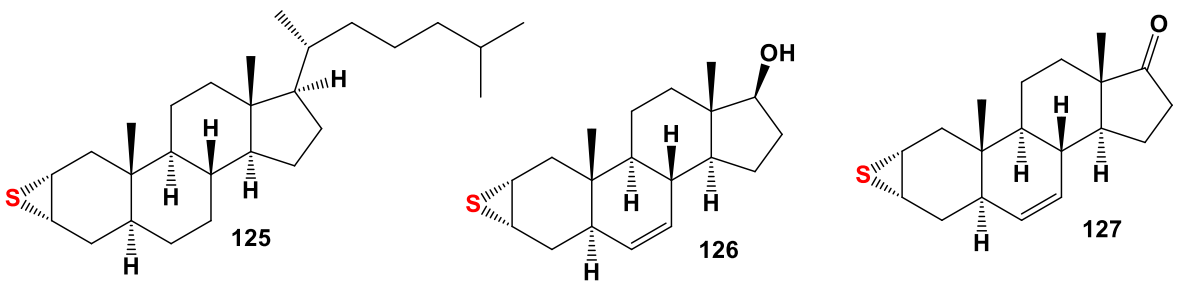<smiles>CC12CC3SC3CC1CC[C@@H]1[C@@H]2CC[C@]2(C)C(=O)CC[C@@H]12</smiles><smiles>CC12CC[C@H]3[C@@H](CC[C@@H]4C[C@@H]5C[C@H]5CC34C)[C@@H]1CCC2OC1CCCCO1</smiles>

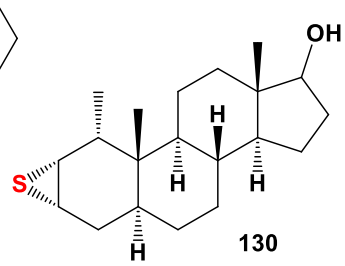

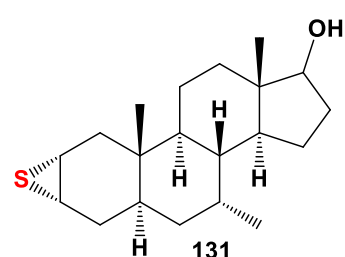

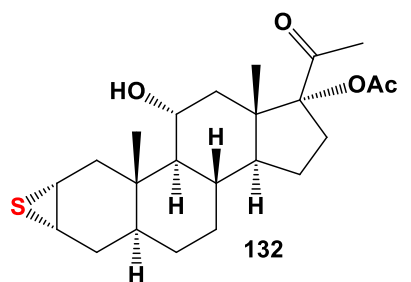

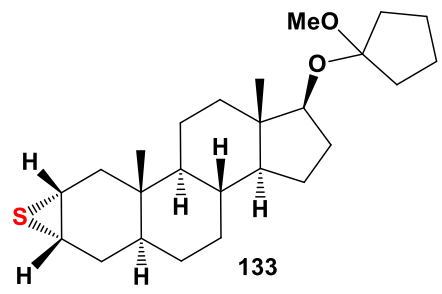

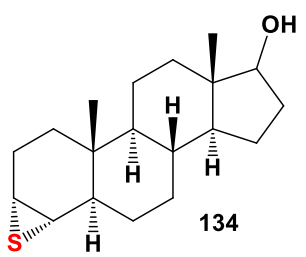

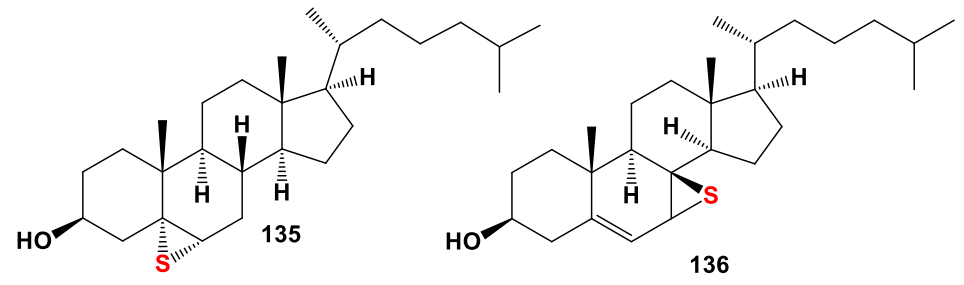

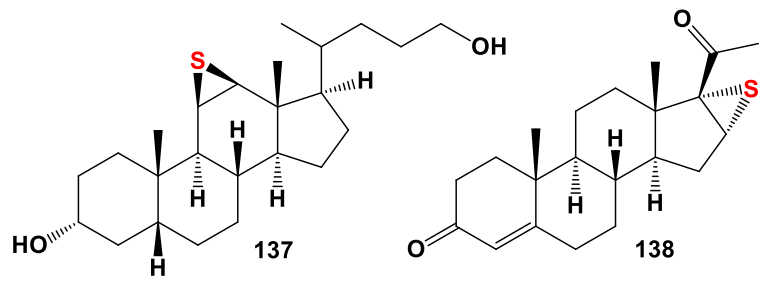

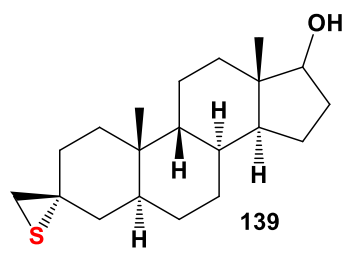

Figure 9. Semi-synthetic and synthetic epithio steroids, and their pharmacological profile is shown in Table 8. 
Table 8. Biological activities of epithio steroids.

\begin{tabular}{|c|c|c|c|}
\hline No. & Antitumor \& Related Activity, $(\mathrm{Pa})$ * & Specific Activities, $(\mathbf{P a}) *$ & Additional Predicted Activity, $(\mathbf{P a})$ * \\
\hline 122 & $\begin{array}{c}\text { Antineoplastic }(0.964) \\
\quad \text { Cytostatic }(0.798) \\
\text { Antineoplastic (breast cancer) }(0.598) \\
\end{array}$ & $\begin{array}{c}\text { Anti-secretoric }(0.948) \\
\text { Estrogen antagonist }(0.860)\end{array}$ & $\begin{array}{l}\text { Erythropoiesis stimulant }(0.760) \\
\text { Cardiotonic }(0.729)\end{array}$ \\
\hline 123 & $\begin{array}{c}\text { Antineoplastic }(0.966) \\
\text { Cytostatic }(0.681) \\
\text { Prostatic (benign) hyperplasia treatment }(0.673)\end{array}$ & Anti-secretoric (0.952) & $\begin{array}{c}\text { Anti-inflammatory }(0.754) \\
\text { Bone diseases treatment }(0.663) \\
\text { Anabolic }(0.648)\end{array}$ \\
\hline 124 & $\begin{array}{c}\text { Antineoplastic }(0.966) \\
\text { Cytostatic }(0.681) \\
\text { Prostatic (benign) hyperplasia treatment }(0.673)\end{array}$ & Anti-secretoric (0.952) & $\begin{array}{c}\text { Anti-inflammatory }(0.754) \\
\text { Bone diseases treatment }(0.663) \\
\text { Anabolic }(0.648)\end{array}$ \\
\hline 125 & Antineoplastic (0.932) & $\begin{array}{c}\text { Anti-secretoric (0.863) } \\
\text { Anti-hypercholesterolemic }(0.759)\end{array}$ & $\begin{array}{l}\text { Anti-eczematic }(0.840) \\
\text { Dermatologic }(0.747) \\
\text { Anti-psoriatic }(0.659)\end{array}$ \\
\hline 126 & $\begin{array}{l}\text { Antineoplastic }(0.955) \\
\text { Cytostatic }(0.676)\end{array}$ & $\begin{array}{c}\text { Anti-secretoric }(0.938) \\
\text { Estrogen antagonist }(0.807)\end{array}$ & $\begin{array}{l}\text { Anti-seborrheic }(0.814) \\
\text { Dermatologic }(0.639)\end{array}$ \\
\hline 127 & Antineoplastic (0.962) & Anti-secretoric (0.841) & \\
\hline 128 & $\begin{array}{c}\text { Antineoplastic }(0.971) \\
\text { Antineoplastic (breast cancer) }(0.671)\end{array}$ & Anti-secretoric (0.861) & $\begin{array}{l}\text { Anti-seborrheic (0.830) } \\
\text { Cardiotonic }(0.701)\end{array}$ \\
\hline 129 & Antineoplastic (0.970) & $\begin{array}{l}\text { Estrogen antagonist }(0.686) \\
\text { Anti-secretoric }(0.677)\end{array}$ & $\begin{array}{c}\text { Cardiotonic }(0.672) \\
\text { Dermatologic }(0.649)\end{array}$ \\
\hline 130 & $\begin{array}{l}\text { Antineoplastic }(0.883) \\
\text { Cytostatic }(0.661)\end{array}$ & $\begin{array}{c}\text { Anti-secretoric }(0.906) \\
\text { Estrogen antagonist }(0.750)\end{array}$ & $\begin{array}{l}\text { Anti-seborrheic }(0.926) \\
\text { Dermatologic }(0.743)\end{array}$ \\
\hline 131 & $\begin{array}{l}\text { Antineoplastic }(0.960) \\
\text { Cytostatic }(0.724)\end{array}$ & $\begin{array}{c}\text { Anti-secretoric }(0.965) \\
\text { Estrogen antagonist }(0.915)\end{array}$ & $\begin{array}{c}\text { Anti-seborrheic }(0.848) \\
\text { Anti-osteoporotic }(0.729)\end{array}$ \\
\hline 132 & $\begin{array}{l}\text { Antineoplastic }(0.939) \\
\text { Cytostatic }(0.787)\end{array}$ & $\begin{array}{c}\text { Anti-secretoric }(0.967) \\
\text { Estrogen antagonist }(0.946)\end{array}$ & $\begin{array}{l}\text { Anti-inflammatory }(0.929) \\
\text { Anti-seborrheic }(0.849)\end{array}$ \\
\hline 133 & $\begin{array}{c}\text { Antineoplastic }(0.974) \\
\text { Prostatic (benign) hyperplasia treatment }(0.583)\end{array}$ & $\begin{array}{l}\text { Estrogen antagonist }(0.870) \\
\text { Anti-secretoric }(0.827)\end{array}$ & $\begin{array}{l}\text { Antiprotozoal (Plasmodium) (0.642) } \\
\text { Anabolic (0.616) }\end{array}$ \\
\hline 134 & Antineoplastic (0.868) & $\begin{array}{c}\text { Cardiotonic }(0.925) \\
\text { Anti-arrhythmic }(0.858)\end{array}$ & $\begin{array}{c}\text { Anti-seborrheic (0.869) } \\
\text { Anti-inflammatory }(0.733)\end{array}$ \\
\hline 135 & Antineoplastic (0.780) & $\begin{array}{l}\text { Anesthetic general }(0.847) \\
\text { Anti-secretoric }(0.804)\end{array}$ & $\begin{array}{c}\text { Anti-eczematic (0.811) } \\
\text { Anti-inflammatory (0.739) }\end{array}$ \\
\hline 136 & $\begin{array}{c}\text { Antineoplastic }(0.779) \\
\text { Apoptosis agonist }(0.707)\end{array}$ & $\begin{array}{c}\text { Cholesterol antagonist }(0.946) \\
\text { Anti-hypercholesterolemic }(0.930)\end{array}$ & $\begin{array}{l}\text { Respiratory analeptic }(0.963) \\
\text { Anesthetic general }(0.913)\end{array}$ \\
\hline 137 & Antineoplastic (0.775) & $\begin{array}{c}\text { Cholesterol antagonist (0.932) } \\
\text { Anti-hypercholesterolemic }(0.900)\end{array}$ & $\begin{array}{c}\text { Anesthetic general }(0.923) \\
\text { Respiratory analeptic }(0.919)\end{array}$ \\
\hline 138 & Antineoplastic (0.912) & Cardiotonic (0.936) & $\begin{array}{l}\text { Respiratory analeptic }(0.781) \\
\text { Anesthetic general }(0.746)\end{array}$ \\
\hline 139 & Antineoplastic (0.768) & Cholesterol antagonist (0.745) & Anti-seborrheic (0.905) \\
\hline
\end{tabular}

* Only activities with $\mathrm{Pa}>0.5$ are shown.

\section{Comparison of Biological Activities of Sulfated and Sulfur-Containing Steroids}

The concept, which was formed more than 150 years ago, that the biological activity of natural and synthetic compounds depends on their chemical structure has been confirmed at the current time [165]. Using this concept, it is generally accepted that the biological activity of both natural and synthetic compounds depends on their chemical structure [166,167]. Apart from the sharp jumps in biological activity that are observed for some medicinal compounds [168], this can be considered a violation of this rule; however, for most chemical compounds, the structure-activity ratio (SAR) is widely used in medicinal chemistry and pharmacology to search for and optimize new pharmacological agents [169].

Software PASS is the first software for in silico estimation of biological activity profiles [170], of which the development was started more than 30 years ago [171]. Its current implementation predicts about 10,000 pharmacological effects, molecular mechanisms 
of action, pharmacological effects, toxicity, side effects, anti-targets, transporters-related interactions, gene expression regulation, and metabolic terms [166]. Due to the utilization of chemical descriptors that reflect the essential features of ligand-target interactions and a robust mathematical approach for analysis of structure-activity relationships, the average accuracy of PASS predictions was 96\% [172]. Based on the PASS predictions provided by the appropriate web-service [173], over 29,000 researchers from 105 countries selected the most promising virtually designed molecules for synthesis and determined the optimal directions for testing their biological activity [174-177].

In this study, PASS predictions were used to estimate the general pharmacological potential for the analyzed natural, semi-synthetic, and synthetic sulfated and sulfurcontaining steroids, and triterpenoids. For about ten thousand pharmacological effects and molecular mechanisms of action, probabilities of belonging to the class of "active" $\mathrm{Pa}$, varied from zero to one, were estimated. PASS estimates are presented as Pa values, which correspond to the probability of belonging to a class of "actives" for each predicted biological activity. The higher the $\mathrm{Pa}$ value is, the higher the probability of confirming the predicted activity in the experiment. On the other hand, estimated Pa values might be relatively small for some activities if the analyzed molecule is not like the active compounds from the PASS training set. Pa values are indicated for all steroids and triterpenoids presented in this article in Tables 1-8.

Since the end of March 2021, a new version of the PASS program has been used, with an increased amount of both natural and synthetic compounds, and, accordingly, the database of biological activities has increased.

\subsection{Antitumor Activity of Natural Mono-, Di-, and Poly-Sulfated Steroids}

Currently, about 7000 articles have been published covering various aspects of marine and terrestrial sulfated steroids and triterpenoids. Analyzing the data obtained using PASS compounds presented in this review, it can be stated that out of 71 marine sulfated steroids and triterpenoids, the activity is estimated with Pa from $68.6 \%$ to $94.8 \%$, and only thirteen marine sulfated steroids demonstrate strong antitumor activity with a reliability of $90 \%$ to $94.8 \%$ (see Tables 1-4 and structures shown in Figures 1-5). However, most sulfated steroids exhibited moderate antitumor activity with $68 \%$ to $90 \%$ confidence. A 3D graph of the predicted antitumor and related activities is shown in Figure 10. In addition, many sulfated steroids exhibit moderate anti-hypercholesterolemic activity, and some steroids exhibit strong anti-hypercholesterolemic activity with a confidence level greater than $90 \%$ (see Figure 11). An interesting finding was that some sulfated steroids show wound-healing properties with more than $90 \%$ confidence, and this data is presented in Figure 12. Several sulfated steroids such as $\mathbf{1}(93.1 \%), 2(92.7 \%)$, and 21 (92.8\%) exhibit hemostatic properties with more than $92 \%$ confidence, and other steroids $29(93.3 \%)$, 32 (93.3\%), 34 (96.8\%), 48 (92.4\%), 65 (91.5\%), 68 (91.5\%), 69 (91.8\%), 70 (93.4\%), and 71 (93.4\%) show hepatoprotective properties (see Tables 1-4).

\subsection{Biological Activity of Sulfur-Containing and Epithio Steroids}

Sulfur-containing steroids are an interesting class of natural lipids, but most of these compounds exhibit weak or moderate antitumor activity. Some steroids have no antitumor activity, and only four steroids have strong antitumor activity. Figure 13 demonstrates the activity of these steroids. In addition, a sulfur-containing steroid called spironolactone (73) excreted from human urine is of interest. According to the PASS data, this steroid is multifunctional and demonstrates seventeen different activities. Figure 14 shows the pharmacological profile of this steroid. One feature should be noted for all sulfur-containing steroids: most of these compounds exhibit dermatological properties such as weak or moderate anti-eczematic and anti-psoriatic activity. 


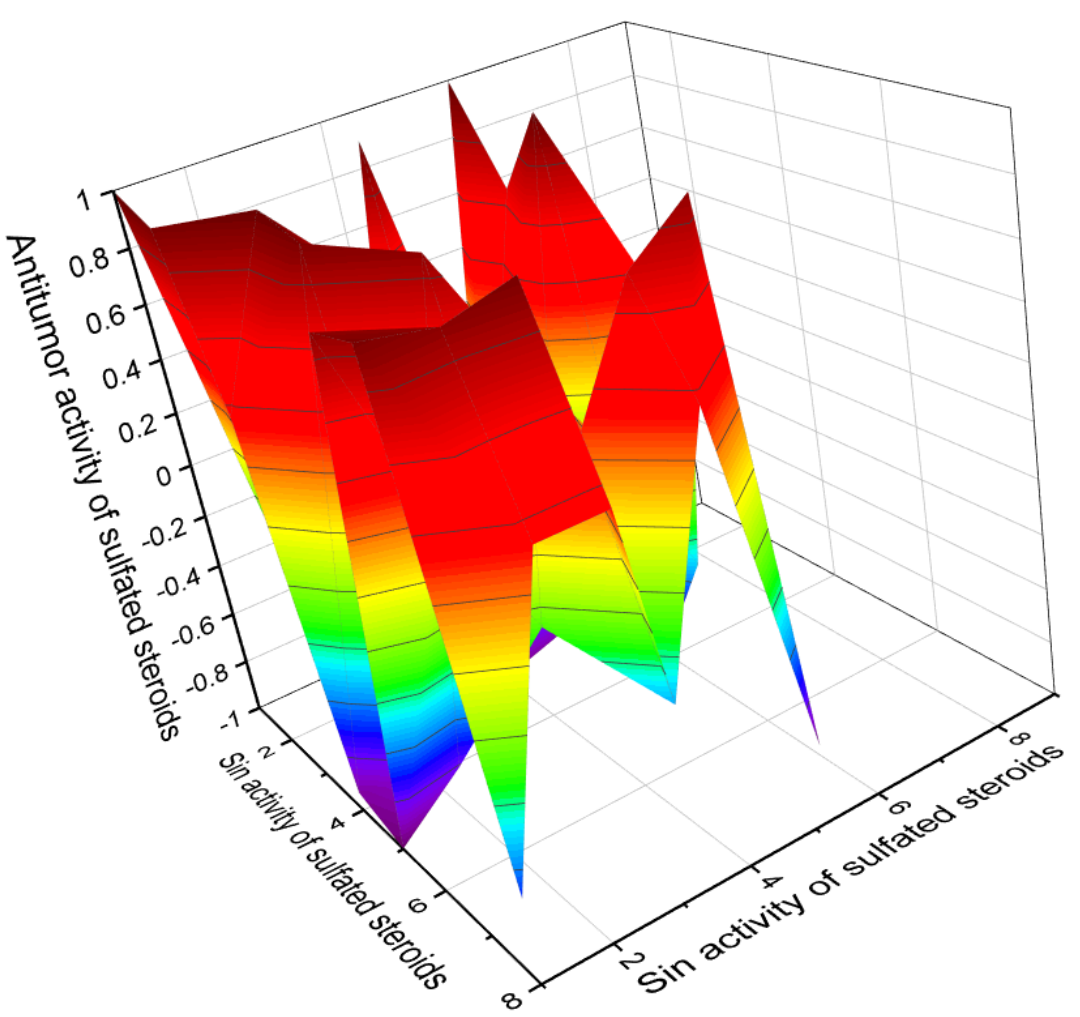

Figure 10. The 3D graph shows the predicted and calculated antitumor activity of selected sulfated steroids (compound numbers: 28, 29, 40, 42, 43, 44, 45, 48, and 64) showing the highest degree of confidence, more than $91 \%$. These sulfated steroids derived from marine sources can be used in clinical medicine as agents with strong antitumor activity.

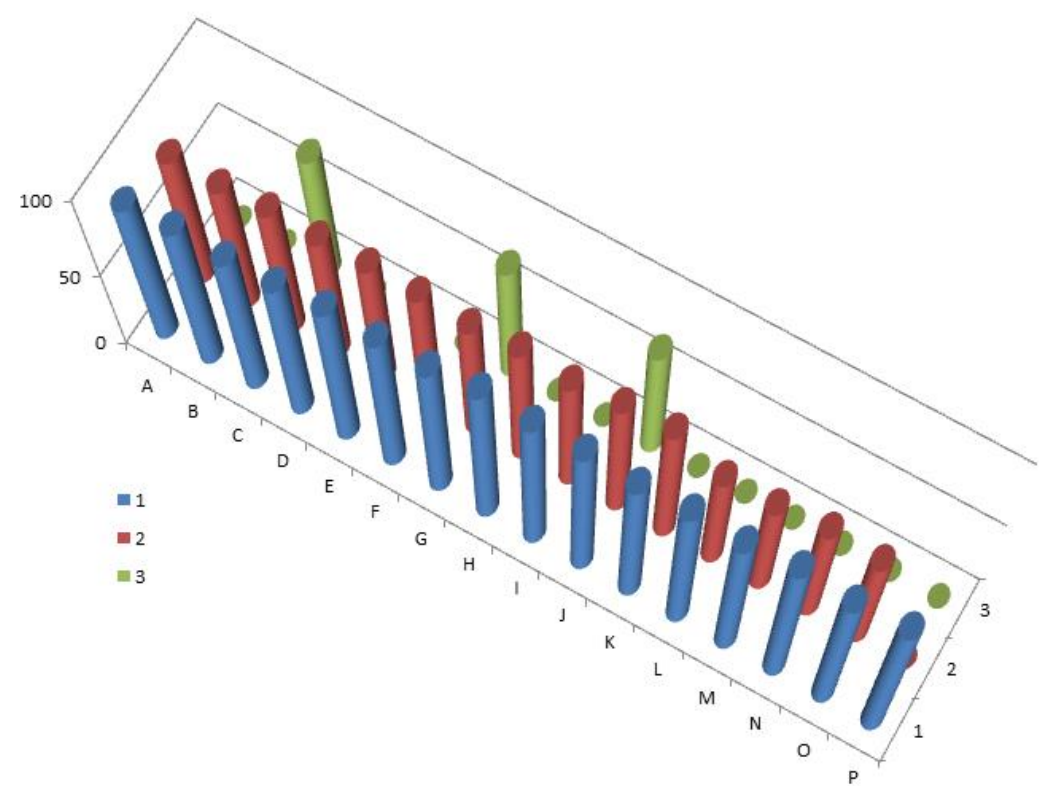

Figure 11. 3D column graph of sulfated steroids derived from marine sources that show antihypercholesterolemic activity. The letters represent the steroid numbers shown in Figures 1-4 and Tables 1-5: A-(1), B-(14), C-(16), D-(18), E-(19), F-(20), G-(21), H-(23), I-(24), J-(26), $\mathrm{K}-(31), \mathrm{L}-(40), \mathrm{M}-(41), \mathrm{N}-(42), \mathrm{O}-(43)$, and $\mathrm{P}-(52)$. Steroids that belong to this group, according to the data obtained by the PASS, have confirmed more than $90 \%$ of their biological activity. 


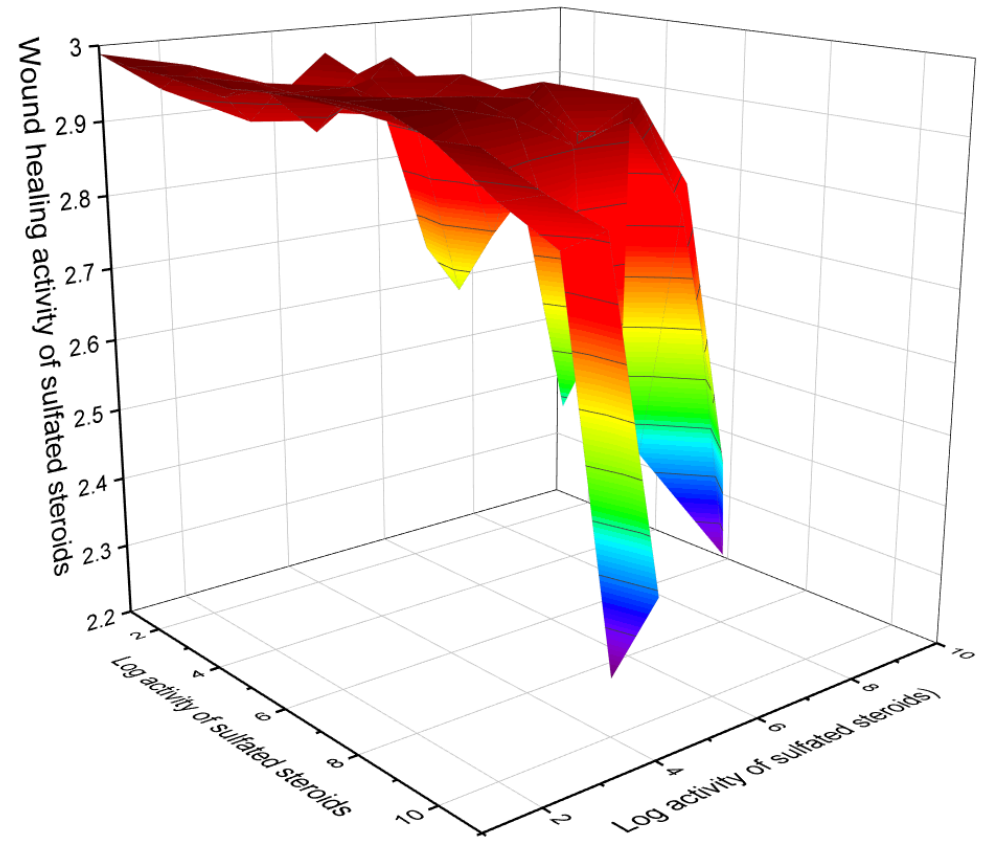

Figure 12. The $3 \mathrm{D}$ graph shows the predicted and calculated wound-healing activity of selected sulfated steroids (compound numbers: 14 (95.5\%), 18 (93.8\%), 19 (95.2\%), 21 (92.8\%), 29 (96.5\%), $40(95.3 \%), 41(96.3 \%), 42(97.5 \%), 43(98.0 \%), 44(97.7 \%), 60(93.3 \%)$, and 61 (94.2\%). These sulfated steroids show the highest degree of confidence, more than $92 \%$.

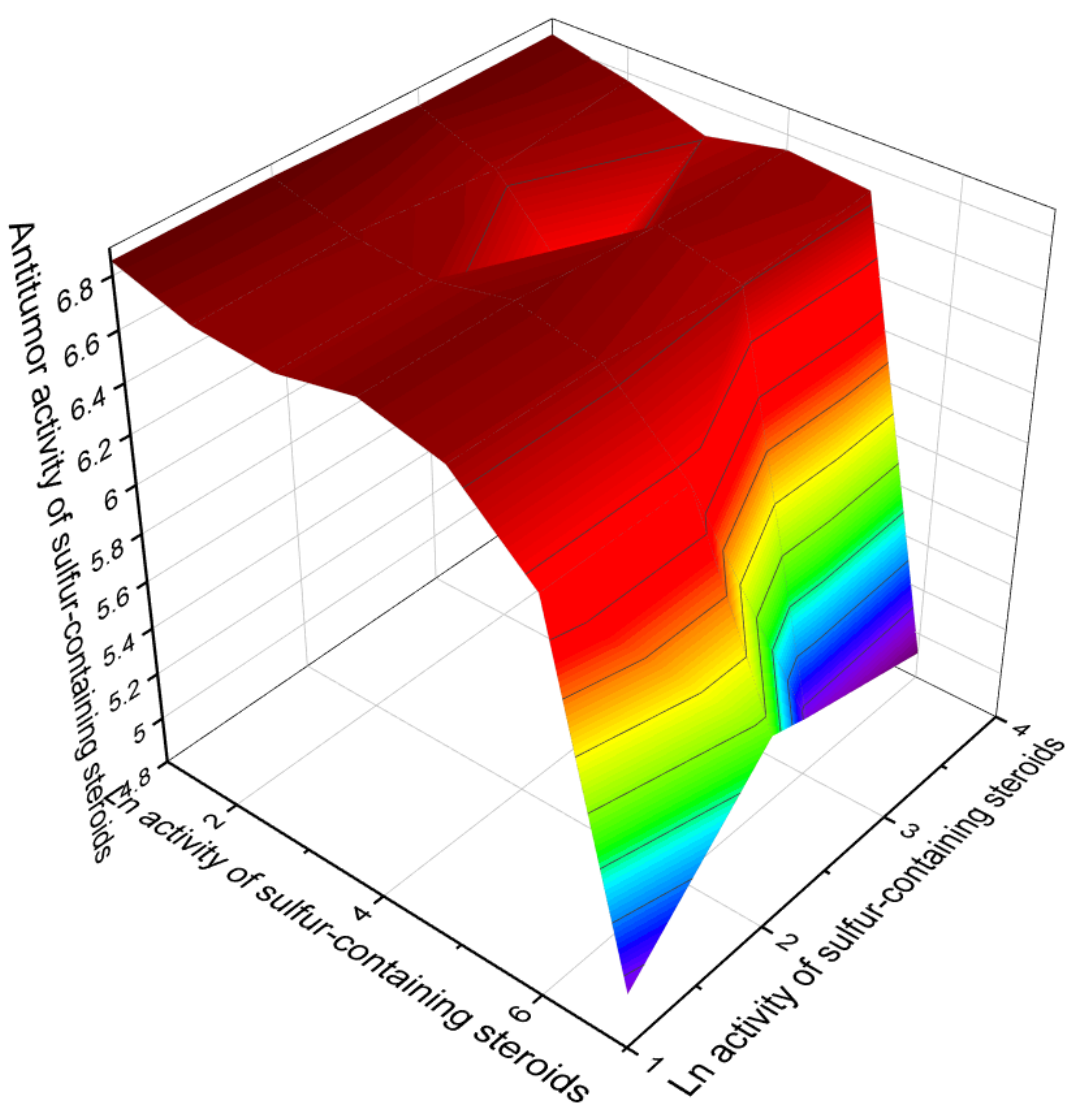

Figure 13. The 3D graph shows the predicted and calculated antitumor activity of selected sulfurcontaining steroids (compound numbers): 98 (94.7\%), 99 (94.7\%), 100 (92.8\%) and 105 (93.3\%). These steroids show the highest degree of confidence, more than $92 \%$. 

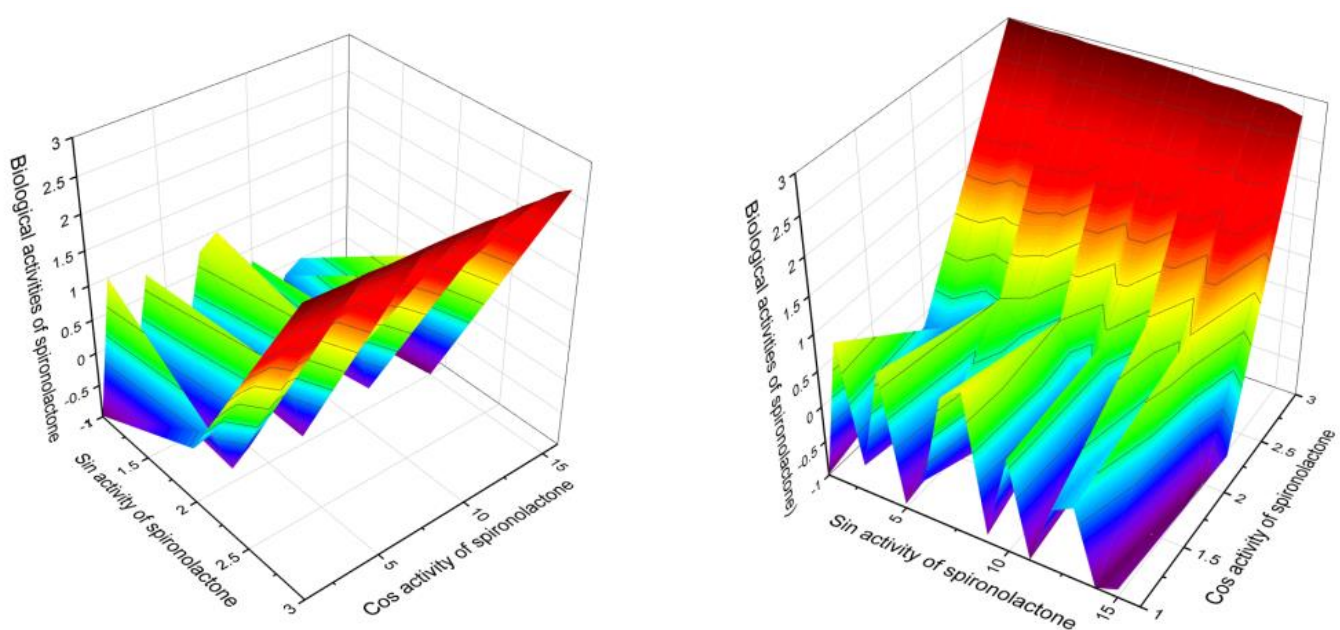

Figure 14. The 3D Graph ( $X$ and $Y$ views) predicted and calculated activities of the spironolactone, which was isolated from the human urine extracts. According to PASS data, this steroid demonstrated seventeen different activities, with five activities having confidence of more than $90 \%$. The main pharmacological properties and activities of spironolactone (73) are diuretic $(99.1 \%)$, anti-hyperaldosteronism (96.3\%), anti-hypertensive (94\%), renal disease treatment (93.4\%), and heart failure treatment $(91.2 \%)$. As shown in numerous publications, spironolactone demonstrates properties as a potential diuretic, antihypertensive agent, or agent for the treatment of renal failure and heart failure, as well as an agent in the treatment of hyperaldosteronism (including Conn's syndrome) and female hirsutism (due to additional antiandrogenic actions). All these properties and activities are confirmed by the PASS data as shown in this figure and shown in Table 5.

Most epithio steroids are classified as anabolic steroids and are used in bodybuilding diets, as well as stimulants by athletes or a specific category of people during physical or physiological stress [152,178-180].

Several epithio steroids shown in Table 7 show strong antitumor activity, and Figure 15 shows the activity of these steroids. In addition, some epithio steroids exhibit antisecretory activity with more than $90 \%$ confidence and can be classified as antisecretory drugs. It is known that the first antisecretory drugs (antimuscarinic) were available in the 1950s, and it was not until the 1970s that the first histamine antagonist appeared. This seems to be a watershed moment in the history of acid peptic ulcer treatment. Later in the 1980s, sulfur-containing ranitidine, omeprazole, lansoprazole, rabeprazole and other proton pump inhibitors, pantoprazole, esomeprazole, and dexlanzoprazole were discovered. Their effectiveness in reducing acid secretion has been associated with side effects such as osteoporosis, malabsorption of iron and vitamin B12, hypomagnesemia, acute and chronic kidney disease, dementia, acute myocardial infarction, Clostridium difficile infection, and others [181-183]. Figure 16 demonstrates the properties of some epithio steroids as potential agents with antisecretory activity.

As shown by the PASS data, the four epithio steroids 122, 123, 129, and 138 exhibit properties to increase the efficiency and improve the contraction of the heart muscle, i.e., are typical cardiotonic agents with a Pa confidence of $70 \%$ to $93.6 \%$. 


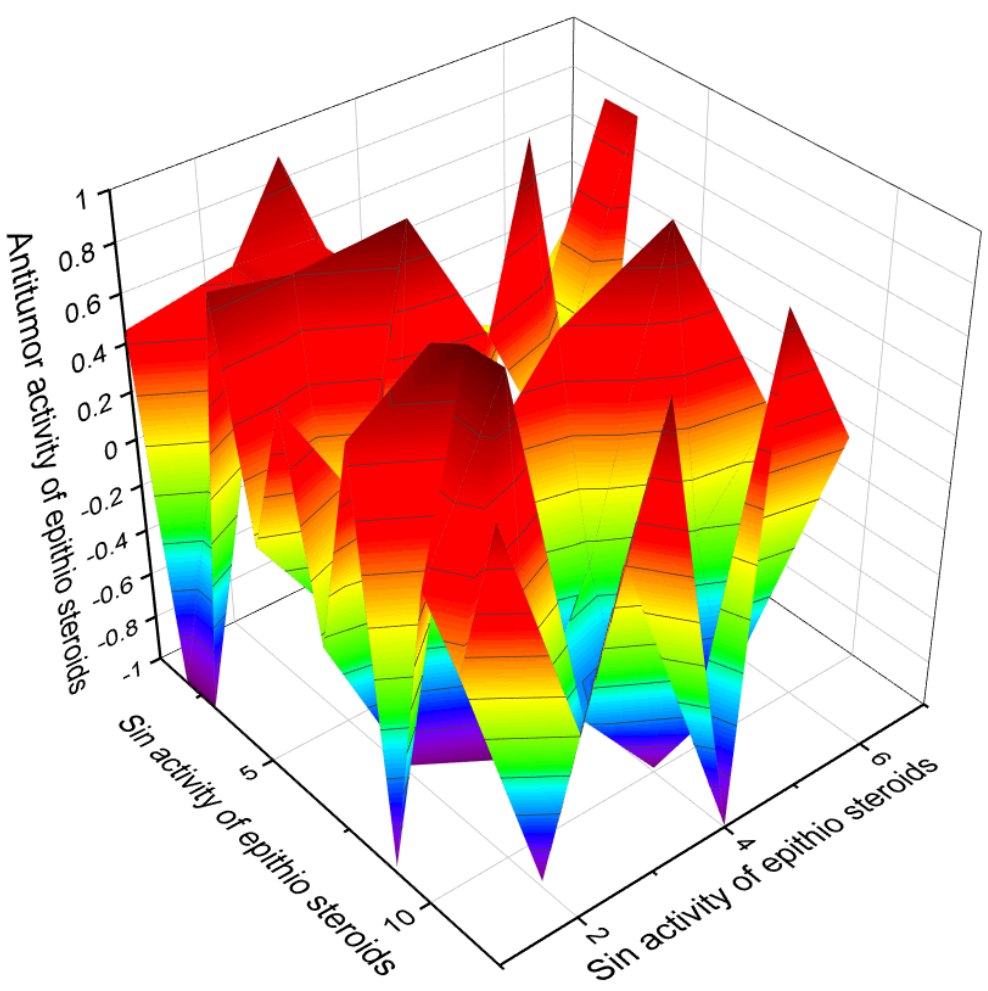

Figure 15. The 3D graph shows the predicted and calculated antitumor activity of selected semi- and synthetic epithio steroids (compound numbers): 122 (96.4\%), $123(96.6 \%), 124(96.6 \%), 125$ (93.2\%), 126 (95.5\%), 127 (96.2\%), 128 (97.1\%), 129 (97.0\%), 131 (96.0\%), $132(93.9 \%), 133(97.4 \%)$, and 138 $(91.2 \%)$. These steroids show the highest degree of confidence, more than $91 \%$.

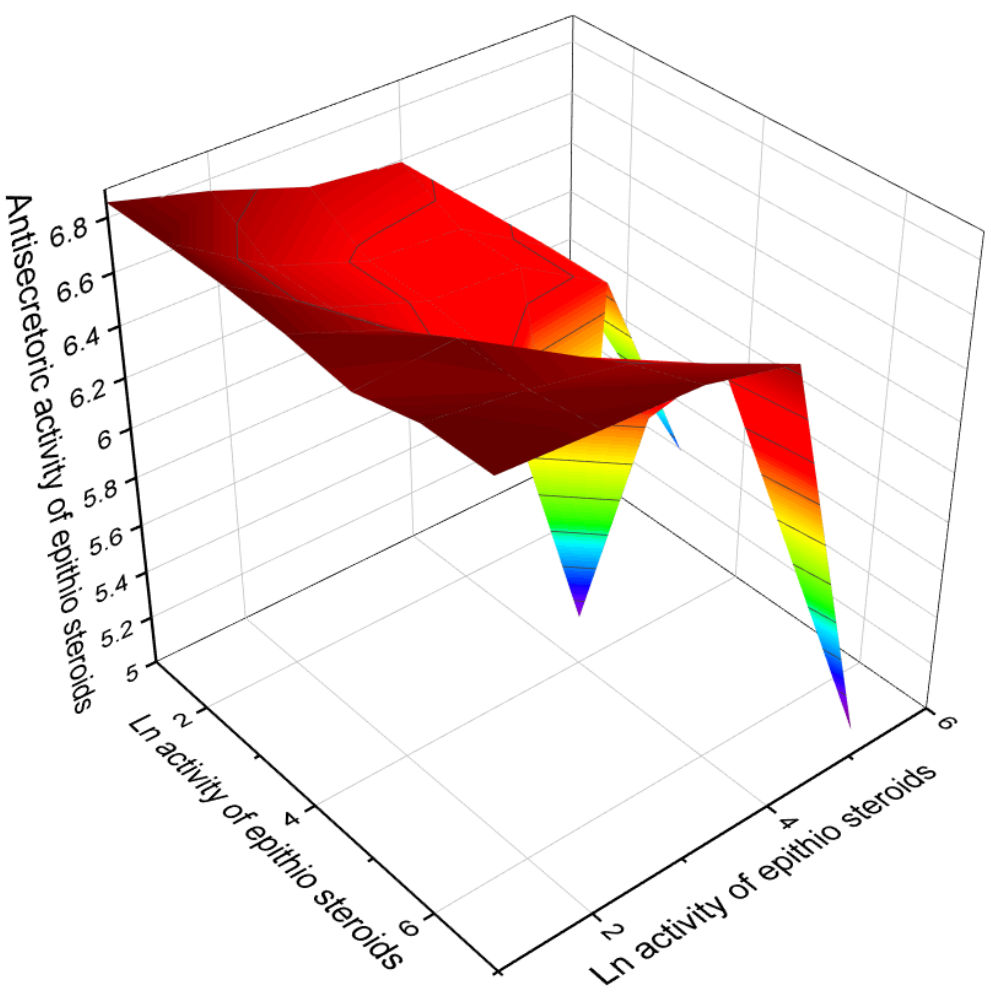

Figure 16. The 3D graph shows the predicted and calculated anti-secretoric activity of some an epithio steroids (compound numbers): 122 (94.8\%), 123 (95.2\%), 124 (95.2\%), 126 (93.8\%), 130 (90.6\%), $131(96.5 \%)$, and 132 (96.7\%). These epithio steroids show the highest degree of confidence, more than $90 \%$. 


\section{Conclusions}

The review focuses on the interesting topic of sulfated steroids, which have been isolated from algae, sea sponges, soft corals, ascidians, starfish, and other marine invertebrates. In addition, sulfur-containing steroids and triterpenoids that are isolated from sedentary marine coelenterates, plants, marine sediments, crude oil, and other geological deposits are also presented in this review. Additionally, several semi-synthetic and synthetic epithiosteroids, which are a rare group of bioactive lipids that have not yet been found in nature but have a high level of antitumor activity, were included in this review for the comparative pharmacological characterization of this class of compounds.

This review presents 139 steroids and triterpenoids that exhibit a broad spectrum of biological activity. The data obtained with the PASS program show that thirteen sulfated steroids exhibit strong antitumor activity with a confidence level of more than $90 \%$. Among the sulfur-containing steroids, only four show strong antitumor activity with a confidence level of more than $93 \%$, although most of the presented epitosteroids show strong antitumor activity with a confidence level of $91 \%$ to $97.4 \%$. These data are of great interest to pharmacologists and clinical physicians.

Author Contributions: Conceptualization, V.M.D. and T.A.P.; methodology, V.M.D.; software, T.A.G.; validation, V.M.D., N.S. and T.A.P.; formal analysis, N.S.; investigation, V.M.D.; data curation, N.S.; writing—original draft preparation, V.M.D.; writing—review and editing, V.M.D. and N.S.; visualization, N.S.; supervision, V.M.D.; project administration, V.M.D.; funding acquisition, T.A.G. All authors have read and agreed to the published version of the manuscript.

Funding: This research received no external funding.

Acknowledgments: The work (GTA) was done in the framework of the Russian Federation fundamental research program for the long-term period of 2021-2030.

Conflicts of Interest: The authors declare no conflict of interest.

\section{References}

1. Muthukumar, J.; Chidambaram, R.; Sukumaran, S. Sulfated polysaccharides and its commercial applications in food industries. A review. J. Food Sci. Technol. 2020. [CrossRef]

2. Kornprobst, J.M.; Sallenave, C.; Barnathan, G. Sulfated compounds from marine organisms. Comp. Biochem. Physiol. Biochem. Mol. Biol. 1998, 119B, 1-51.

3. Mougous, J.D.; Green, R.E.; Williams, S.J. Sulfotransferases and sulfatases in mycobacteria. Chem. Biol. 2002, 9, 767-776. [CrossRef]

4. Cunha, L.; Grenha, A. Sulfated seaweed polysaccharides as multifunctional materials in drug delivery applications. Mar. Drugs 2016, 14, 42. [CrossRef]

5. Da Silva, M.C.; Sousa, E.; Pinto, M.M.M. Emerging sulfated flavonoids and other polyphenols as drugs: Nature as an inspiration. Med. Res. Rev. 2014, 34, 223-279. [CrossRef] [PubMed]

6. Dembitsky, V.M. Chemistry and biodiversity of the biologically active natural glycosides. Chem. Biodivers. 2004, 1, 673-781. [CrossRef]

7. Almeida, J.R.; Da-Silva, M.C.; Sousa, E. Antifouling potential of nature-inspired sulfated compounds. Sci. Rep. 2017, 7, 42424. [CrossRef] [PubMed]

8. Teles, Y.C.F.; Sallett, M.; Souza, R. Sulphated flavonoids: Biosynthesis, structures, and biological activities. Molecules 2018, 23, 480. [CrossRef] [PubMed]

9. Dembitsky, V.M. Antitumor and hepatoprotective activity of natural and synthetic neo steroids. Prog. Lipid Res. 2020, 79, 101048. [CrossRef] [PubMed]

10. Stonik, V.A.; Kicha, A.A.; Malyarenko, T.V.; Ivanchina, N.V. Asterosaponins: Structures, taxonomic distribution, biogenesis and biological activities. Mar. Drugs 2020, 18, 584. [CrossRef]

11. Mensah-Nyagan, A.G.; Beaujean, D.; Do-Rego, J.L. In vivo evidence for the production of sulfated steroids in the frog brain. Comp. Biochem. Physiol. Biochem. Mol. Biol. 2000, 126, 213-219. [CrossRef]

12. Pauli, G.F.; Friesen, J.B.; Gödecke, T. Occurrence of progesterone and related animal steroids in two higher plants. J. Nat. Prod. 2010, 73, 338-345. [CrossRef]

13. Mueller, J.W.; Gilligan, L.C.; Idkowiak, J. The regulation of steroid action by sulfation and desulfation. Endocrin. Rev. 2015, 36, 526-563. [CrossRef] [PubMed]

14. Suchański, J.; Ugorski, M. The biological role of sulfatides. Postepy Hig. Med. Dosw. (Online) 2016, 70, 489-504. [CrossRef]

15. D'Auria, M.V.; Minale, L.; Riccio, R. Polyoxygenated steroids of marine origin. Chem. Rev. 1993, 93, 1839-1895. [CrossRef] 
16. Carvalhal, F.; Correia-da-Silva, M.; Sousa, M.E. Sources and biological activities of marine sulfated steroids. J. Mol. Endocrinol. 2018. [CrossRef]

17. D'Auria, M.V.; Paloma, L.G.; Minale, L. Isolation and structure characterization of two novel bioactive sulphated polyhydroxysteroids from the Antarctic Ophiuroid, Ophioderma longicaudum. Nat. Prod. Lett. 1993, 3, 197-208. [CrossRef]

18. Stonik, V.A. Marine polar steroids. Russ. Chem. Rev. 2001, 70, 673-715. [CrossRef]

19. Stonik, V.A.; Ivanchina, N.V.; Kicha, A.A. New polar steroids from starfish. Nat. Prod. Commun. 2008, 3, 158-172. [CrossRef]

20. Savidov, N.; Gloriozova, T.A.; Dembitsky, V.M. Pharmacological activities of sulphated steroids derived from marine sources. Life Sci. Press. 2018, 2, 48-58.

21. Kellner Filho, L.C.; Picão, B.W.; Silva, M.L.A.; Cunha, W.R.; Pauletti, P.M.; Dias, G.M.; Copp, B.R.; Bertanha, C.S.; Januario, A.H. Bioactive aliphatic sulfates from marine invertebrates. Mar. Drugs 2019, 17, 527. [CrossRef]

22. Burdige, D.J. Geochemistry of Marine Sediments; Princeton University Press: Princeton, NJ, USA, 2007. [CrossRef]

23. Volkman, J.K. Lipids of Geochemical Interest in Microalgae. In Hydrocarbons, Oils and Lipids: Diversity, Origin, Chemistry and Fate; Wilkes, H., Ed.; Handbook of Hydrocarbon and Lipid Microbiology; Springer: Cham, Switzerland, 2020. [CrossRef]

24. Volkman, J.K. A review of sterol markers for marine and terrigenous organic matter. Org. Geochem. 1986, 9, 83-99. [CrossRef]

25. Harris, P.T. The fate of microplastic in marine sedimentary environments: A review and synthesis. Mar. Pollut. Bull. 2020, 158, 111398. [CrossRef]

26. La Rowe, D.E.; Arndt, S.; Bradley, J.A.; Estes, E.R.; Hoarfrostf, A.; Langg, S.Q.; Lloydh, K.G. The fate of organic carbon in marine sediments-New insights from recent data and analysis. Earth Sci. Rev. 2020, 204, 103146. [CrossRef]

27. Núñez-Pons, L.; Shilling, A.; Verde, C.; Baker, B.J.; Giordano, D. Marine terpenoids from polar latitudes and their potential applications in biotechnology. Mar. Drugs 2020, 18, 401. [CrossRef] [PubMed]

28. Volkman, J.K.; Holdsworth, D.G.; Neill, G.P.; Bavor, H.J., Jr. Identification of natural, anthropogenic and petroleum hydrocarbons in aquatic sediments. Sci. Total Environ. 1992, 112, 203-219. [CrossRef]

29. Dembitsky, V.M. Ether lipids of the organic world: Formation and biotransfor-mation. In Fats for Future; Cambie, R.C., Ed.; Ellis Horwood Ltd. Publ.: Oxford, UK, 1989; Chapter 12; pp. 173-188.

30. Volkman, J. Sterols in microorganisms. Appl. Microbiol. Biotech. 2003, 60, 495-506. [CrossRef]

31. Cranwell, P.A. Lipids of aquatic sediments and sedimenting particulates. Prog. Lipid Res. 1982, 21, 271-308. [CrossRef]

32. Dembitsky, V.M.; Gloriozova, T.A. Naturally occurring boron containing compounds: Structures and biological activities. J. Nat. Prod. Resour. (India) 2017, 3, 147-152.

33. Volkman, J.K.; Barrett, S.M.; Blackburn, S.I.; Mansour, M.P.; Sikes, E.L.; Gelin, F. Microalgal biomarkers: A review of recent research developments. Org. Geochem. 1998, 29, 1163-1179. [CrossRef]

34. Aufartová, J.; Mahugo-Santana, C.; Sosa-Ferrera, Z.; Santana-Rodríguez, J.J.; Nováková, L.; Solich, P. Determination of steroid hormones in biological and environmental samples using green microextraction techniques: An overview. Anal. Chim. Acta 2011, 704, 33-46. [CrossRef] [PubMed]

35. Dembitsky, V.M.; Smoum, R.; Al-Quntar, A.A.; Ali, H.A.; Pergament, I.; Srebnik, M. Natural occurrence of boron-containing compounds in plants, algae and microorganisms. Plant Sci. 2002, 163, 931-942. [CrossRef]

36. Dembitsky, V.M.; Quntar, A.; Srebnik, M. Natural and synthetic small boron-containing molecules as potential inhibitors of bacterial and fungal quorum sensing. Chem. Rev. 2011, 111, 209-237. [CrossRef]

37. Wolkenstein, K.; Gross, J.H.; Falk, H. Boron-containing organic pigments from a Jurassic red alga. Proc. Natl. Acad. Sci. USA 2010, 107, 19374-19378. [CrossRef]

38. Wolkenstein, K.; Sun, H.; Falk, H.; Griesinger, C. Structure and absolute configuration of Jurassic polyketide-derived spiroborate pigments obtained from microgram quantities. J. Am. Chem. Soc. 2015, 137, 13460-13463. [CrossRef] [PubMed]

39. Summons, R.E.; Jahnke, L.L.; Simoneit, B.R. Lipid biomarkers for bacterial ecosystems: Studies of cultured organisms, hydrothermal environments and ancient sediments. Ciba Found. Symp. 1996, 202, 174-193.

40. Ajikumar, P.K.; Tyo, K.; Carlsen, S.; Mucha, O.; Phon, T.H.; Stephanopoulos, G. Terpenoids: Opportunities for biosynthesis of natural product drugs using engineered microorganisms. Mol. Pharm. 2008, 5, 167-190. [CrossRef]

41. Lamers, L.P.M.; van Diggelen, O.; Op den Camp, H.J.M.; Visser, E.J.W.; Lucassen, E.C.; Vile, A.; Jetten, M.S.M.; Smolders, A.J.P.; Roelofs, J.G.M. Microbial transformations of nitrogen, sulfur, and iron dictate vegetation composition in wetlands: A Review. Front. Microbiol. 2012, 3, 156-171. [CrossRef] [PubMed]

42. Hunt, H.W.; Stewart, J.W.B.; Cole, C.V. Concepts of sulfur, carbon, and nitrogen transformations in soil: Evaluation by simulation modelling. Biogeochemistry 1986, 2, 163-177. [CrossRef]

43. Weisskopf, L.; Schulz, S.; Garbeva, P. Microbial volatile organic compounds in intra-kingdom and inter-kingdom interactions. Nat. Rev. Microbiol. 2021. [CrossRef]

44. Bruisson, S.; Berg, G.; Garbeva, P.; Weisskopf, L. Volatile interplay between microbes: Friends and Foes. In Bacterial Volatile Compounds as Mediators of Airborne Interactions; Ryu, C.M., Weisskopf, L., Piechulla, B., Eds.; Springer: Singapore, 2020. [CrossRef]

45. Ullah, A.; Bano, A.; Janjua, H.T. Microbial secondary metabolites and defense of plant stress. Microb. Serv. Restorat. Ecol. 2020, $11,37-46$.

46. Lee, Y.J.; Cho, Y.; Tran, H.N.K. Secondary metabolites from the marine sponges of the genus Petrosia: A literature review of 43 years of research. Mar. Drugs 2021, 19, 122. [CrossRef] 
47. Roy, S.R.; Minei, A.; Ahmadi, P.; Hermawan, I.; Kurnianda, V.; Dick, M.H.; Tanaka, J. Two new steroid sulfates from a cheilostome bryozoan, Calyptotheca sp. Nat. Prod. Res. 2020. [CrossRef]

48. Kicha, A.A.; Malyarenko, T.V.; Kalinovsky, A.I.; Popov, R.S.; Malyarenko, O.S.; Ermakova, S.P.; Ivanchina, N.V. Polar steroid compounds from the Arctic starfish Asterias microdiscus and their cytotoxic properties against normal and tumor cells in vitro. Nat. Prod. Res. 2020. [CrossRef] [PubMed]

49. Ivanchina, N.V.; Kicha, A.A.; Huong, T.T.; Kalinovsky, A.I.; Dmitrenok, P.S.; Agafonova, I.G.; Long, P.Q.; Stonik, V.A. Highly hydroxylated steroids of the starfish Archaster typicus from the Vietnamese waters. Steroids 2010, 75, 897-904. [CrossRef] [PubMed]

50. Kaluzhskiy, L.A.; Shkel, T.V.; Ivanchina, N.I.; Kicha, A.A.; Grabovec, I.P.; Gilep, A.A. Structural analogues of lanosterol from marine organisms of the class Asteroidea as potential inhibitors of human and Candida albicans lanosterol $14 \alpha$-demethylases. Nat. Prod. Commun. 2017, 12, 1843-1846. [CrossRef]

51. Shubina, L.K.; Makarieva, T.N.; Denisenko, V.A.; Popov, R.S.; Dyshlovoy, S.A.; Grebnev, B.B.; Dmitrenok, P.S.; von Amsberg, G.; Stonik, V.A. Gracilosulfates A-G, monosulfated polyoxygenated steroids from the marine sponge Haliclona gracilis. Mar. Drugs 2020, 18, 454. [CrossRef]

52. Ivanchina, N.V.; Kicha, A.A.; Malyarenko, T.V.; Ermolaeva, S.D.; Yurchenko, E.A.; Pislyagin, E.A.; van Minh, C.; Dmitrenok, P.S. Granulatosides D, E and other polar steroid compounds from the starfish Choriaster granulatus. Their immunomodulatory activity and cytotoxicity. Nat. Prod. Res. 2019, 33, 2623-2630. [CrossRef]

53. Palagiano, E.; Zollo, F.; Minale, L.; Gomez Paloma, L.; Iorizzi, M.; Bryan, P.; McClintock, J.; Hopkins, T.; Riou, D.; Roussakis, C. Downeyosides A and B, two new sulfated steroid glucuronides from the starfish Henricia downeyae. Tetrahedron 1995, 51, 12293-12300. [CrossRef]

54. Palagiano, E.; Zollo, F.; Minale, L.; Iorizzi, M.; Bryan, P.; McClintock, J.; Hopkins, T. Isolation of 20 glycosides from the starfish Henricia downeyae, collected in the Gulf of Mexico. J. Nat. Prod. 1996, 59, 348-354. [CrossRef]

55. Björkman, L.R.; Karlsson, K.A.; Pascher, I.; Samuelsson, B.E. The identification of large amounts of cerebroside and cholesterol sulfate in the sea star. Asterias rubens. Biochim. Biophys. Acta 1972, 270, 260-265. [CrossRef]

56. Björkman, L.R.; Karlsson, K.A.; Nilsson, K. On the existence of cerebroside and cholesterol sulfate in tissues of the sea star. Asterias rubens. Comp. Biochem. Physiol. 1972, 43, 409-410.

57. Makarieva, T.N.; Stonik, V.A.; Kapustina, I.I. Biosynthetic studies of marine lipids. 42. Biosynthesis of steroid and triterpenoid metabolites in the sea cucumber Eupentacta fraudatrix. Steroids 1993, 58, 508-517. [CrossRef]

58. Kates, M.; Volcani, B.E. Lipids of diatoms. Biochem. Biophys. Acta 1966, 116, 264-272. [CrossRef]

59. Kobayashi, M.; Ishibashi, M.; Nakamura, H. Hymenosulphate, a novel sterol sulphate with Ca-releasing activity from the cultured marine haptophyte Hymenomonas sp. J. Chem. Soc. Perkin Trans. 1 1989, 2, 101-103. [CrossRef]

60. Gallo, C.; d'Ippolito, G.; Nuzzo, G.; Sardo, A.; Fontana, A. Autoinhibitory sterol sulfates mediate programmed cell death in a bloom-forming marine diatom. Nat. Commun. 2017, 8, 1292-1301. [CrossRef] [PubMed]

61. Thao, N.P.; Luyen, B.T.; Kim, E.J. Steroidal constituents from the edible sea urchin Diadema savignyi Michelin induce apoptosis in human cancer cells. J. Med. Food 2015, 18, 45-53. [CrossRef]

62. Anjaneyulu, A.S.R.; Venugopal, M.J.R.V.; Minale, L.; Iorizzi, M.; Pelagiano, E. Chemical examination of a sea cucumber of Holothuria genus of the Indian Ocean. Indian J. Chem. 1998, 37B, 262-268.

63. Prinsep, M.R.; Blunt, J.W.; Munro, M.H.G. A new sterol sulfate from the marine sponge Stylopus australis. J. Nat. Prod. 1989, 52, 657-659. [CrossRef]

64. Makarieva, T.N.; Stonik, V.A.; D'yachuk, O.G.; Dmitrenok, A.S. Annasterol sulfate, a novel marine sulfated steroid, inhibitor of glucanase activity from the deep water sponge Poecillastra laminaris. Tetrahedron Lett. 1995, 36, 129-134. [CrossRef]

65. Nakatsu, T.; Walker, R.P.; Thompson, J.E.; Faulkner, D.J. Biologically active sterol sulfates from the marine sponge Toxadocia zumi. Experientia 1983, 39, 759-761. [CrossRef]

66. Li, H.Y.; Matsunaga, S.; Fusetani, N.; Fujiki, H. Echinoclasterol sulfate phenethyl-ammonium salt, a unique steroid sulfate from the marine sponge. Echinoclathria subhispida. Tetrahedron Lett. 1993, 34, 5733-5736. [CrossRef]

67. Sperry, S.; Crews, P. Haliclostanone sulfate and halistanol sulfate from an Indo-Pacific Haliclona sponge. J. Nat. Prod. 1997, 60, 29-32. [CrossRef]

68. Aiello, A.; Fattorusso, E.; Menna, M. New cytotoxic steroids from the marine sponge Dysidea fragilis coming from the lagoon of Venice. Steroids 1995, 60, 666-673. [CrossRef]

69. Ivanchina, N.V.; Kicha, A.A.; Kalinovsky, A.I. Hemolytic polar steroidal constituents of the starfish Aphelasterias japonica. J. Nat. Prod. 2000, 63, 1178-1182. [CrossRef] [PubMed]

70. Tsukamoto, S.; Matsunaga, S.; Fusetani, N.; van Soest, R.W.M. Acanthosterol sulfates A-J: ten new antifungal steroidal sulfates from a marine songe Acanthodendrilla sp. J. Nat. Prod. 1998, 61, 1374-1378. [CrossRef]

71. Iorizzi, M.; Bryan, P.; McClintock, J. Chemical and biological investigation of the polar constituents of the starfish Luidia clathrata, collected in the Gulf of Mexico. J. Nat. Prod. 1995, 58, 653-658. [CrossRef] [PubMed]

72. Andriyaschenko, P.V.; Levina, E.V.; Kalinovsky, A.I. Chemistry of natural compounds and bioorganic chemistry: Steroid compounds from the Pacific starfishes Luidia quinaria and Distolasterias elegans. Izv. Akad. Nauk Ser. Khim. 1996, 3, $473-481$.

73. Lee, Y.J.; Han, S.; Kim, S.H. Three new cytotoxic steroidal glycosides isolated from Conus pulicarius collected in Kosrae, Micronesia. Mar. Drugs 2017, 15, 379. [CrossRef] [PubMed] 
74. Malyarenko, T.V.; Malyarenko-Vishchuk, O.S.; Ivanchina, N.V. Four new sulfated polar steroids from the Far Eastern starfish Leptasterias ochotensis: Structures and activities. Mar. Drugs 2015, 13, 4418-4435. [CrossRef]

75. Imperatore, C.; D'Aniello, F.; Aiello, A. Phallusiasterols A and B: Two new sulfated sterols from the Mediterranean tunicate Phallusia fumigata and their effects as modulators of the PXR receptor. Mar. Drugs 2014, 12, 2066-2078. [CrossRef]

76. Kicha, A.A.; Ivanchina, N.V.; Kalinovsky, A.I. Asterosaponin P2 857 from the Far-Eastern starfish Patiria (Asterina) pectinifera. Russ. Chem. Bull. 2000, 49, 1794-1795. [CrossRef]

77. Peng, Y.; Zheng, J.; Huang, R.; Wang, Y.; Xu, T. Polyhydroxy steroids and saponins from China sea starfish Asterina pectinifera and their biological activities. Chem. Pharm. Bull. 2010, 58, 856-858. [CrossRef] [PubMed]

78. De Riccardis, F.; Minale, L.; Riccio, R. A novel group of polyhydroxycholanic acid derivatives from the deep-water starfish Styracaster caroli. Tetrahedron Lett. 1993, 34, 4381-4384. [CrossRef]

79. Kong, F.; Andersen, R.J. Polymastiamides B-F, novel steroid/amino acid conjugates isolated from the Norwegian marine sponge Polymastia boletiformis. J. Nat. Prod. 1996, 59, 379-385. [CrossRef]

80. Kong, F.; Andersen, R.J. Polymastiamide A, a novel steroid/amino acid conjugate isolated from the Norwegian marine sponge Polymastia boletiformis (Lamarck, 1815). J. Org. Chem. 1993, 58, 6924-6928. [CrossRef]

81. Chludil, H.D.; Maier, M.S. Minutosides A and B, antifungal sulfated steroid xylosides from the patagonian starfish Anasterias minuta. J. Nat. Prod. 2005, 68, 1279-1283. [CrossRef] [PubMed]

82. Koehn, F.E.; Gunasekera, M.; Cross, S.S. New antiviral sterol disulfate ortho esters from the marine sponge Petrosia weinbergi. J. Org. Chem. 1991, 56, 1322-1325. [CrossRef]

83. Sun, H.H.; Gross, S.S.; Gunaseker, M.; Koehn, F.E. Weinbersterol disulfates A and B, antiviral steroid sulfates from the sponge petrosia weinbergi. Tetrahedron 1991, 47, 1185-1190. [CrossRef]

84. McKee, T.C.; Cardellina II, J.H.; Riccio, R.; D'Auria, M.V.; Iorizzi, M.; Minale, L.; Moran, R.A.; Gulakowski, R.J.; McMahon, J.B. HIV-inhibitory natural products. 11. Comparative studies of sulfated sterols from marine invertebrates. J. Med. Chem. 1994, 37, 793-797. [CrossRef] [PubMed]

85. Finamore, E.; Zollo, F.; Minale, L.; Yasumoto, T. Starfish saponins, part 47. Steroidal glycoside sulfates and polyhydroxysteroids from Aphelasterias japonica. J. Nat. Prod. 1992, 55, 767-771. [CrossRef]

86. Dembitsky, V.M. Lipids of marine origin. A study of Ophiura sarsi phospholipids. Bioorg Chem. (USSR) 1980, 6, $426-429$.

87. Sato, D.; Ando, Y.; Tsujimoto, R. Identification of novel nonmethylene-interrupted fatty acids, 7E,13E-20:2, 7E,13E,17Z20:3,9E,15E,19Z-22:3, and 4Z,9E,15E,19Z-22:4, in Ophiuroidea (Brittle star) lipids. Lipids 2001, 36, 1371-1378. [CrossRef] [PubMed]

88. Dembitsky, V.M. Plasmalogens in phospholipids of marine invertebrates. Biol. Morya (Vladivostok) 1979, 5, 86-90.

89. Dembitsky, V.M. Betaine ether-linked glycerolipids: Chemistry and biology. Prog. Lipid Res. 1996, 35, 1-51. [CrossRef]

90. Dembitsky, V.M.; Srebnik, M. Natural halogenated fatty acids: Their analogues and derivatives. Prog. Lipid Res. 2002, 41, 315-367. [CrossRef]

91. Dembitsky, V.M.; Vaskovsky, V.E. A quantitative distribution of plasmalogens in different phospholipid classes of marine invertebrates. Biol. Morya (Vladivostok) 1976, 5, 68-72.

92. Shubina, L.K.; Fedorov, S.N.; Levina, E.V. Comparative study on polyhydroxylated steroids from echinoderms. Comp. Biochem. Physiol. 1998, 119B, 505-516. [CrossRef]

93. Voogt, P.A. Biosynthesis and composition of 3-sterols in the ophiuroids Ophiura albida and Ophioderma longicauda. Comp. Biochem. Physiol. 1973, 45B, 593-601. [CrossRef]

94. Comin, M.J.; Maier, M.S.; Roccatagliata, A.J. Evaluation of the antiviral activity of natural sulfated polyhydroxysteroids and their synthetic derivatives and analogs. Steroids 1999, 64, 335-340. [CrossRef]

95. Levina, E.V.; Andriyaschenko, P.V.; Kalinovsky, A.I. New Ophiuroid-type steroids from the starfish Pteraster tesselatus. J. Nat. Prod. 1998, 61, 1423-1429. [CrossRef]

96. Fusetani, N.; Matsunaga, S.; Konosu, S. Bioactive marine metabolites II. Halistanol sulfate, an antimicrobial novel steroid sulfate from the marine sponge Halichondria cf. moorei bergquist. Tetrahedron Lett. 1981, 22, 1985-1991. [CrossRef]

97. Nakamura, F.; Kudo, N.; Tomachi, Y. Halistanol sulfates I and J, new SIRT1-3 inhibitory steroid sulfates from a marine sponge of the genus Halichondria. J. Antibiot. 2018, 71, 273-278. [CrossRef] [PubMed]

98. Chen, M.; Wu, X.D.; Zhao, Q.; Wang, C.Y. Topsensterols A-C, cytotoxic polyhydroxylated sterol derivatives from a marine sponge Topsentia sp. Mar. Drugs 2016, 14, 146. [CrossRef] [PubMed]

99. Whitson, E.L.; Bugni, T.S.; Chockalingam, P.S. Spheciosterol sulfates, PKCzeta inhibitors from a philippine sponge Spheciospongia sp. J. Nat. Prod. 2008, 71, 1213-1217. [CrossRef] [PubMed]

100. Berdyshev, E.V. Fatty aldehydes of the phosphatidylethanolamines of marine invertebrates. Chem. Nat. Compd. 1989, 25, 525-529. [CrossRef]

101. Hanuš, L.O.; Levitsky, D.O.; Shkrob, I.; Dembitsky, V.M. Plasmalogens, fatty acids and alkyl glyceryl ethers of marine and freshwater clams and mussels. Food Chem. 2009, 116, 491-498. [CrossRef]

102. Dembitsky, V.M. Quantification of plasmalogen, alkylacyl and diacyl glycerophospholipids by micro-thin-layer chromatography. J. Chromatogr. 1988, 436A, 467-473. [CrossRef] 
103. Dembitsky, V.M.; Gorina, I.A.; Fedorova, I.P.; Solovieva, M.V. Comparative investigation of plasmalogens, alkylacyl and diacyl glycerophospholipids of the marine sponges (type Porifera, class Demospongiae). Comp. Biochem. Physiol. 1989, 92, 733-736. [CrossRef]

104. Berdyshev, E.V. Mass spectrometry of fatty aldehydes. Biochim. Biophys. Acta 2011, 1811, 680-693. [CrossRef]

105. Sheikh, Y.M.; Kaisin, M.; Djerassi, C. Steroids from starfish. Steroids 1973, 22, 835-850. [CrossRef]

106. Whitson, E.L.; Bugni, T.S.; Prdiya, S.; Chockalingam, P.S. Fibrosterol sulfates from the Philippine sponge Lissodendoryx (Acan-

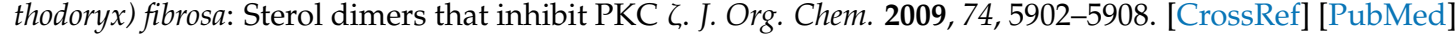

107. Makarieva, T.N.; Shubina, L.K.; Kalinovsky, A.I. Steroids in porifera. II. Steroid derivatives from two sponges of the family. Sokotrasterol sulfate, a marine steroid with a new pattern of side chain alkylation. Steroids 1983, 42, 267-271. [CrossRef]

108. Gunasekera, S.P.; Sennett, S.H.; Kelly-Borges, M. Ophirapstanol trisulfate, a new biologically active steroid sulfate from the deep-water marine sponge Topsentia ophiraphidites. J. Nat. Prod. 1994, 57, 1751-1754. [CrossRef] [PubMed]

109. Yurchenko, A.N.; Girich, E.V.; Yurchenko, E.A. Metabolites of marine sediment-derived fungi: Actual trends of biological activity studies. Mar. Drugs 2021, 19, 88. [CrossRef]

110. Chiang, Y.R.; Ismail, W. Anaerobic biodegradation of steroids. In Anaerobic Utilization of Hydrocarbons, Oils, and Lipids, Handbook of Hydrocarbon and Lipid Microbiology; Boll, M., Ed.; Springer Nature Switzerland AG: Basel, Switzerland, 2020; pp. 165-195.

111. Mazurek, M.A.; Simoneit, B.R.T. Higher molecular weight terpenoids as indicators of organic emissions from terrestrial vegetation. ACS Symp. Ser. 1997, 671, 92-108.

112. Pancost, R.D.; Pressley, S.; Coleman, J.M.; Benning, L.G.; Mountain, B.W. Lipid biomolecules in silica sinters: Indicators of microbial biodiversity. Environ. Microbiol. 2005, 7, 66-77. [CrossRef]

113. Sinninghe Damsté, J.S.; De Leeuw, J.W.; Kock-Van Dalen, A.C.; De Zeeuw, M.A. The occurrence and identification of series of organic sulphur compounds in oils and sediment extracts. I. A study of Rozel Point Oil (U.S.A.). Geochim. Cosmochim. Acta 1987, 51, 2369-2391. [CrossRef]

114. De Leeuw, J.W.; Sinninghe Damsté, J.S. Organic sulfur compounds and other biomarkers as indicators of paleosalinity. ACS Symp. Ser. 1990, 429, 417-443.

115. Zamanpour, M.K.; Kaliappan, R.S.; Rockne, K.J. Gas ebullition from petroleum hydrocarbons in aquatic sediments: A review. J. Environ. Manag. 2020, 271, 110997. [CrossRef] [PubMed]

116. Dembitsky, V.M.; Savidov, N.; Poroikov, V.V.; Gloriozova, T.A.; Imbs, A.B. Naturally occurring aromatic steroids and their biological activities. Appl. Microbiol. Biotechnol. 2018, 102, 4663-4674. [CrossRef]

117. Dembitsky, V.M. Astonishing diversity of natural surfactants: 5. Biologically active glycosides of aromatic metabolites. Lipids 2005, 40, 869-900. [CrossRef] [PubMed]

118. Riolo, J.; Hussler, G.; Albrecht, P.; Connan, J. Distribution of aromatic steroids in geological samples: Their evaluation as geochemical parameters. Org. Geochem. 1986, 10, 981-990. [CrossRef]

119. Dembitsky, V.M.; Savidov, N.; Gloriozova, T.A. Natural sulphur-containing steroids: Origin and biological activities. Vietnam J. Chem. 2018, 56, 533-541. [CrossRef]

120. Jørgensen, B.B.; Findlay, A.J.; Pellerin, A. The biogeochemical sulfur cycle of marine sediments. Front. Microbiol. 2019, 10, 849. [CrossRef] [PubMed]

121. Chen, Y.; Shen, L.; Huang, T.; Chu, Z.; Xie, Z. Transformation of sulfur species in lake sediments at Ardley Island and Fildes Peninsula, King George Island, Antarctic Peninsula. Sci. Total Environ. 2020, 703, 135591. [CrossRef] [PubMed]

122. Tang, K. Chemical diversity and biochemical transformation of biogenic organic sulfur in the ocean. Front. Mar. Sci. 2020, 7, 68. [CrossRef]

123. Stebbins, A.; Algeo, T.J.; Krystynd, L.; Rowe, H.; Brookfield, M.; Williams, J.; Nye, S.W., Jr.; Hannigan, R. Marine sulfur cycle evidence for upwelling and eutrophic stresses during Early Triassic cooling events. Earth Sci. Rev. 2019, 195, 68-82. [CrossRef]

124. Amend, J.P.; Edwards, K.J.; Lyons, T.W. Sulfur biogeochemistry: Past and present. Geol. Soc. Amer. 2004, 379. [CrossRef]

125. Darnet, S.; Schaller, H. Metabolism and biological activities of 4-methyl-sterols. Molecules 2019, 24, 451. [CrossRef]

126. Mandal, S.; Bhattacharya, S.; Roy, C.; Rameez, M.J.; Sarkar, J.; Mapder, T.; Fernandes, S.; Peketi, A.; Mazumdar, A.; Ghosh, W. Cryptic roles of tetrathionate in the sulfur cycle of marine sediments: Microbial drivers and indicators. Biogeosciences 2020, 17, 4611-4631. [CrossRef]

127. Shen, Y.; Thiel, V.; Suarez-Gonzalez, P.; Rampen, S.W.; Reitner, J. Sterol preservation in hypersaline microbial mats. Biogeosciences 2020, 17, 649-666. [CrossRef]

128. Huang, X.; Deng, Z.; Zhu, X.; van Ofwegen, L.; Proksch, P.; Lin, W. Krempenes A-D: A series of unprecedented pregnane-type steroids from the marine soft coral Cladiella krempfi. Helv. Chim. Acta 2006, 89, 2020-2026. [CrossRef]

129. Karim, A.; Brown, E.A. Isolation and identification of novel sulfur-containing metabolites of spironolactone (Aldactone ${ }^{\circledR}$ ). Steroids 1972, 20, 41-62. [CrossRef]

130. de Marvao, A.; Alexander, D.; Bucciarelli-Ducci, C. Heart disease in women: A narrative review. Anaesthesia 2021, 76, 118-130. [CrossRef] [PubMed]

131. Segar, J.L. Neonatal diuretic therapy: Furosemide, thiazides, and spironolactone. Clin. Perinatol. 2012, 39, 209-220. [CrossRef] [PubMed]

132. Colussi, G.L.; Catena, C.; Sechi, L.A. Spironolactone, eplerenone and the new aldosterone blockers in endocrine and primary hypertension. J. Hyperten. 2013, 31, 3-15. [CrossRef] 
133. Carone, L.; Oxberry, S.G.; Twycross, R. Spironolactone. J. Pain Symptom Manag. 2017, 53, 288-292. [CrossRef]

134. Ruba, A.A.; Mohan, V.R. GC-MS analysis of active compounds in the whole plant of Andrographis echioides (L) nees (Acanthaceae). Eur. J. Biomed. Pharm. Sci. 2014, 1, 443-452.

135. El Fels, L. Suivi Physico-Chimique, Microbiologique et Écotoxicologique du Compostage de Boues de. STEP Mélangées à des Déchets de Palmier: Validation de Nouveaux Indices de Maturité. Ph.D. Thesis, Institut National Polytechnique de Toulouse, Toulouse, France, 2014.

136. El Fels, L.; El Ouaqoudi, F.-Z.; Lemee, L.; Geffroy, C.; Ambles, A.; Hafidi, M. Occurrence of plant and fecal steroid and their evolution during co-composting of sewage sludge and lignocellulosic waste. Biochem. Eng. J. 2016, 105, 497-504. [CrossRef]

137. Kohnen, M.E.L.; Sinninghe Damsté, J.S.; Haven, H.T.L.; Ckock-Van Dalen, A.; Schouten, S.; De Leeuw, J.W. Identification and geochemical significance of cyclic di-and trisulphides with linear and acyclic isoprenoid carbon skeletons in immature sediments. Geochim. Cosmochim. Acta 1991, 55, 3685-3695. [CrossRef]

138. Sinninghe Damsté, J.S.; Kohnen, M.E.L.; Baas, M.; Kock-van Dalen, A.C.; de Leeuw, J.W. Sulphur-bound steroid and phytane carbon skeletons in geomacromolecules: Implications for the mechanism of incorporation of sulphur into organic matter. Geochim. Cosmochim. Acta 1993, 57, 2515-2528.

139. Lu, H.; Peng, P.; Hsu, C.S. Geochemical explication of sulfur organics characterized by Fourier transform ion cyclotron resonance mass spectrometry on sulfur-rich heavy oils in Jinxian Sag, Bohai Bay basin, Northern China. Energy Fuels 2013, 27, 5861-5866. [CrossRef]

140. Adam, P.; Schneckenburger, P.; Schaeffer, P.; Albrecht, P. Clues to early diagenetic sulfurization processes from mild chemical cleavage of labile sulfur-rich geomacromolecules. Geochim. Cosmochim. Acta 2000, 64, 3485-3503. [CrossRef]

141. Lu, H.; Wang, Q.T.; Jiang, L.X. Identification and formation of sulfur-containing steroids in sulfur-rich heavy oils in the Jinxian Sag, Bohai Bay Basin, North China. Sci. China Earth Sci. 2013. [CrossRef]

142. Sinninghe Damsté, J.S.; Rijpstra, W.I.C.; Kock-van Dalen, A.C.; de Leeuw, J.W.; Schenck, P.A. The occurrence and identification of series of organic sulphur compounds in oils and sediment extracts II. Their presence in samples from hypersaline and non-hypersaline depositional environments and possible application as source, palaeo environmental and maturity indicators. Geochim. Cosmochim. Acta 1989, 53, 1323-1341.

143. Sinninghe Damsté, J.S.; Schouten, S.; de Leeuw, J.W.; Tvan Duin, A.C.; Geenevasen, J.A.J. Identification of novel sulfurcontaining steroids in sediments and petroleum: Probable incorporation of sulfur into 85,7 -sterols during early diagenesis. Geochim. Cosmochim. Acta 1999, 63, 31-38. [CrossRef]

144. Schouten, S.; Sephton, S.; Baas, M.; Sinninghe Damsté, J.S. Steroid carbon skeletons with unusually branched C-3 alkyl side chains in sulphur-rich sediments. Geochim. Cosmochim. Acta 1998, 62, 1127-1132. [CrossRef]

145. Van Kaam-Peters, H.M.E.; Rijpstra, W.I.C.; De Leeuw, J.W.; Sinninghe Damsté, J.S. A high-resolution biomarker study of different lithofacies of organic sulfur-rich carbonate rocks of a Kimmeridgian lagoon (French southern Jura). Org. Geochem. 1998, 28, 151-177. [CrossRef]

146. Werne, J.P.; Hollander, D.J.; Behrens, A.; Schaeffer, P.; Albrecht, P.; Sinninghe Damsté, J.S. Timing of early diagenetic sulfurization of organic matter: A precursor-product relationship in Holocene sediments of the anoxic Cariaco Basin, Venezuela. Geochim. Cosmochim. Acta 2000, 64, 1741-1751. [CrossRef]

147. Poinsot, J.; Schneckenburger, P.; Adam, P.; Schaeffer, P.; Trendel, J.M.; Riva, A.; Albrecht, P. Novel polycyclic sulfides derived from regular polyprenoids in sediments: Characterization, distribution, and geochemical significance. Geochim. Cosmochim. Acta 1998, 62, 805-814. [CrossRef]

148. Strausz, O.P.; Lown, E.M.; Payzant, J.D. Nature and geochemistry of sulfur-containing compounds in Alberta petroleums. In Geochemistry of Sulfur in Fossil Fuels; American Chemical Society: Washington, DC, USA, 1990; Chapter 22; pp. $366-396$.

149. Petrov, P.D.; Fernández-Murga, L.; Conde, I. Epistane, an anabolic steroid used for recreational purposes, causes cholestasis with elevated levels of cholic acid conjugates, by upregulating bile acid synthesis (CYP8B1) and cross-talking with nuclear receptors in human hepatocytes. Arch. Toxicol. 2020, 94, 589-607. [CrossRef] [PubMed]

150. Weththasinghe, S.A. Synthesis and in vitro Metabolism Studies of Selected Steroids for Anti-Doping Analysis. Ph.D. Thesis, Australian National University, Canberra, Australia, 2020.

151. Li, X.; Rhee, D.K.; Malhotra, R.; Mayeur, C.; Hurst, L.A.; Ager, E. Progesterone receptor membrane component-1 regulates hepcidin biosynthesis. J. Clin. Invest. 2016, 126, 389-401. [CrossRef] [PubMed]

152. Dembitsky, V.M.; Gloriozova, T.A.; Poroikov, V.V. Pharmacological activities of epithio steroids. J. Pharm. Res. Intern. 2017, 18, 1-19. [CrossRef]

153. Díaz, F.C.; Sáez-González, E.; Benlloch, S.; Álvarez-Sotomayor, D. Albumin dialysis with MARS for the treatment of anabolic steroid-induced cholestasis. Ann. Hepatol. 2016, 15, 939-943.

154. Okano, M.; Sato, M.; Ikekita, A. Analysis of non-ketoic steroids $17 \alpha$-methyl-epithiostanol and desoxy-methyl-testosterone in dietary supplements. Drug Test. Anal. 2009, 1, 518-525.

155. Ichihashi, T.; Kinoshita, H.; Yamada, H. Absorption and disposition of epithiosteroids in rats: Avoidance of first-pass metabolism of mepitiostane by lymphatic absorption. Xenobiotica 1991, 21, 873-880. [CrossRef] [PubMed]

156. Abbate, V.; Kicman, A.T.; Evans-Brown, M.; McVeigh, J. Anabolic steroids detected in bodybuilding dietary supplements-a significant risk to public health. Drug Test. Anal. 2014. [CrossRef] [PubMed] 
157. Waller, C.C.; Weththasinghe, S.A.; McClure, L.; Cawley, A.T.; Suann, C.; Suann, E.; Sutherland, E.; Cooper, E.; Heather, A.; McLeod, M.D. In vivo metabolism of the designer anabolic steroid hemapolin in the thoroughbred horse. Drug Test. Anal. 2020, 12, 752-762. [CrossRef]

158. Izuo, M.; Yoshida, M.; Tominaga, T.; Abe, O.; Enomoto, K. A phase III trial of oral high-dose methoxy-progesterone acetate versus mepitiostane in advanced postmenopausal breast cancer. Cancer 1985, 56, 2576-2579. [CrossRef]

159. Komeno, T. Steromal 2,3-Diol Cyclic Trithiocarbonate. U.S. Patent 3,139,128, 19 December 1961.

160. Korneno, T.; Kawanami, E. 11,12-Epithio Steroids of Pregnane Series. U.S. Patent 3,160,627, 8 December 1964.

161. Komeno, T. 2,3-Epithio-Steroids and Production Thereof. U.S. Patent 3,230,215, 18 January 1966.

162. Komeno, T. 2,3-Epithio-5-Androst-6-ene Compounds. U.S. Patent 379778, 25 December 1967.

163. Kellis, J.T., Jr.; Childers, W.E.; Robinson, C.; Vickery, L.E. Inhibition of aromatase cytochrome P-450 by 10-oxirane and 10-thiirane substituted androgens. J. Biol. Chem. 1987, 262, 4421-4426. [CrossRef]

164. Takeda, K.; Komeno, T.; Kawanami, J.; Ishihara, S. Bile acids and steroids. XXVII: Thiosteroids (12)1 steroidal 2,3- and 3,4episulphides and related compounds. Tetrahedron 1965, 21, 329-351. [CrossRef]

165. Brown, A.C.; Fraser, T.R. The connection of chemical constitution and physiological action. Trans. Roy. Soc. Edinburg 1868, 25, 224-242.

166. Poroikov, V.V. Computer-aided drug design: From discovery of novel pharmaceutical agents to systems pharmacology. Biochemistry (Moscow) 2020, 14B, 216-227. [CrossRef]

167. Vázquez, J.; López, M.; Gibert, E.; Herrero, E.; Luque, F.J. Merging ligand-based and structure-based methods in drug discovery: An overview of combined virtual screening approaches. Molecules 2020, 25, 4723. [CrossRef] [PubMed]

168. Stumpfe, D.; Hu, H.; Bajorath, J. Evolving concept of activity cliffs. ACS Omega 2019, 4, 14360-14368. [CrossRef]

169. Wermuth, C.G.; Aldous, D.; Raboisson, R.; Rognan, D. (Eds.) The Practice of Medicinal Chemistry, 4th ed.; Academic Press: Amsterdam, The Netherlands, 2015; p. 902.

170. Mervin, L.H.; Afzal, A.M.; Drakakis, G.; Lewis, R.; Engkvist, O.; Bender, A. Target prediction utilizing negative bioactivity data covering large chemical space. J. Cheminform. 2015, 7, 51. [CrossRef]

171. Burov, Y.V.; Poroikov, V.V.; Korolchenko, L.V. National system for registration and biological testing of chemical compounds: Facilities for new drugs search. Bull. Natl. Center Biol. Act. Comp. 1990, 1, 4-25.

172. Filimonov, D.A.; Druzhilovskiy, D.S.; Lagunin, A.A.; Gloriozova, T.A.; Rudik, A.V.; Dmitriev, A.V.; Pogodin, P.V.; Poroikov, V.V. Computer-aided prediction of biological activity spectra for chemical compounds: Opportunities and limitations. Biomed. Chem. Res. Meth. 2018, 1, e00004. [CrossRef]

173. Available online: http:/ / www.way2drug.com/passonline/ (accessed on 2 March 2021).

174. Ermolenko, E.V.; Imbs, A.B.; Gloriozova, T.A.; Poroikov, V.V.; Sikorskaya, T.V.; Dembitsky, V.M. Chemical diversity of soft coral steroids and their pharmacological activities. Mar. Drugs 2020, 18, 613. [CrossRef]

175. Horishny, V.; Kartsev, V.; Matiychuk, V.; Geronikaki, A.; Anthi, P.; Pogodin, P.; Poroikov, V.; Ivanov, M.; Kostic, M.; Sokovic, M.D. 3-Amino-5-(indol-3-yl) methylene-4-oxo-2-thioxothiazolidine derivatives as antimicrobial agents: Synthesis, computational and biological evaluation. Pharmaceuticals 2020, 13, 229. [CrossRef]

176. Amiranashvili, L.; Nadaraia, N.; Merlani, M.; Kamoutsis, C.; Petrou, A.; Geronikaki, A.; Pogodin, P.; Druzhilovskiy, D.; Poroikov, V.; Ciric, A. Antimicrobial activity of nitrogencontaining 5-alpha-androstane derivatives: In silico and experimental studies. Antibiotics 2020, 9, 224. [CrossRef] [PubMed]

177. Dembitsky, V.M.; Ermolenko, E.; Savidov, N.; Gloriozova, T.A.; Proroikov, V.V. Antiprotozoal and antitumor activity of natural polycyclic endoperoxides: Origin, structures and biological activity. Molecules 2021, 26, 686. [CrossRef] [PubMed]

178. Vizer, S.A.; Sycheva, E.S.; Al Quntar, A.A.A.; Kurmankulov, N.B.; Yerzhanov, K.B.; Dembitsky, V.M. Propargylic sulfides: Synthesis, properties, and application. Chem. Rev. 2015, 115, 1475-1502. [CrossRef] [PubMed]

179. Levitsky, D.O.; Gloriozova, T.A.; Poroikov, V.V.; Dembitsky, V.M. Anabolic cyanosteroids and their biological activities-A brief review. World J. Pharm. Pharm. Sci. 2017, 6, 127-151.

180. Poroikov, V.V.; Gloriozova, T.A.; Dembitsky, V.M. Natural occurring thiirane containing compounds: Origin, chemistry, and their pharmacological activities. Pharm. Chem. J. 2017, 4, 107-120.

181. Lazcano-Becerra, M.; Velarde-Ruiz, V.J.A.; Aldana-Ledesma, J.M.; Gómez-Castaños, P.C.; Díaz-Aceves, P.E.; García-Jiménez, E.S. Antisecretory drug evolution: Pharmacology and clinical uses. Rev. Médica MD 2019, 10, 175-184.

182. Patel, D.; Bertz, R.; Ren, S. A systematic review of gastric acid-reducing agent-mediated drug-drug interactions with orally administered medications. Clin. Pharmacokinet. 2020, 59, 447-462. [CrossRef] [PubMed]

183. Tiwari, P.; Malik, J.K. A comprehensive review on botanical as anti-ulcer therapeutics: Prospective avenues of biocompatible drug discovery. Scholars Int. J. Tradition. Complem. Med. 2020, 3, 27-32. [CrossRef] 